\title{
الجدل في القرآن الكريم والمناهج الفلسفية: السفسطائية والديالكتيك أنموذجا
}

\section{Debate in the Qur'an and the Philosophical Approaches: Sophism and Dialecticism as Examples}

\author{
Syed Mohammad Hilmi Syed Abdul Rahman \\ Department of 'Aqidah and Islamic Thought, Academy of Islamic Studies, \\ University of Malaya, 50603 Kuala Lumpur, Malaysia. smhilmi@um.edu.my \\ Mohammad Abdelhamid Salem Qatawneh \\ Department of 'Aqidah and Islamic Thought, Academy of Islamic Studies, \\ University of Malaya, 50603 Kuala Lumpur, Malaysia. qatawneh@um.edu.my
}

DOI: https://doi.org/10.22452/usuluddin.vol48no1.8

\begin{abstract}
This study attempts to show the importance of the Qur'anic debate in the manifestation of truth and its role in synchronising the rational and natural aspects in order to arrive at the ascertained truth. It also aims to unveil the philosophical approaches of sophism and dialecticism as two examples of the Western method of argumentation. The study further examines the Qur'anic concept of debate and its implementations. In contrast, the study explains the Western philosophical approaches, its foundations, including epistemological and philosophical theories. Furthermore, it analyses the application of Qur'anic debate to explain the rules that the Qur'an practices when arguing with the opponent. In this context, the study uses the comparative and descriptive approach towards the foundations and methods of sophism and dialecticism on one side and the Qur'an on the other. The study finds that the sophist argument is based on the principle of absolute scepticism that does not recognise the certainty of truth. The study also reveals the roots of the dialecticism which is based on the perpetual conflict between reality and human mind. The study further describes the scientific method of the Qur'an to reach the truth through proof, sensual and mental evidences that require a well-developed natural instinct and the fallacy of circular reasoning and infinite regress.
\end{abstract}

Keywords: the Qur'an, debate, sophism, dialecticism, truth, argument, evidence, proof

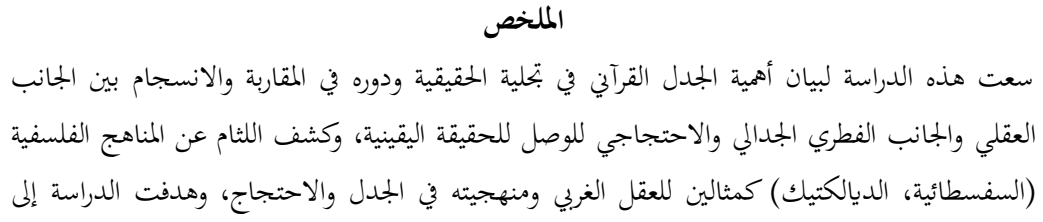


محاولة الإسهام في بحلية مفهوم الجلدل القرآني وتطبيقاته، ومحاولة الوقوف على المناهج الفلسفية في العقل

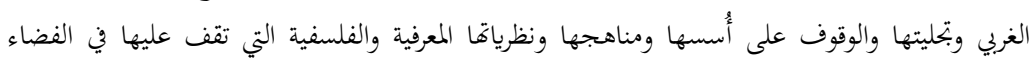

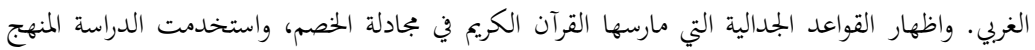
المقارن والوصفي القائم على مقارنة النصوص المهتمة في أسس ومناهج كل من السفسطائية والديالكتيك الكراك

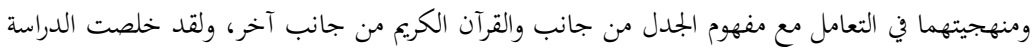

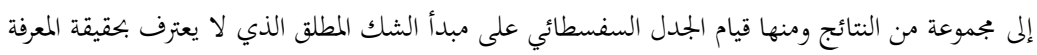
اليقينية، وكذلك كشفت الدراسة جذور الجدل الديالكتي القائم على ديمومة الصراع من الواقع إلى الفكر

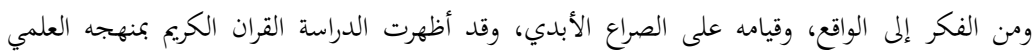
للوصول للحقائق من خلال البرهان والدليل الحسي والعقلي المستلزم لسلامة الفطرة وعدم قبوله الجدل البدل القائم على الدور والتسلسل اللامتناهي نظريا وواقعياً. الكلمات الدالة: القرآن، الجدل، السفسطائية، الديالكتيك، الحقيقة، الحجة، الدليل، البرهان

\section{المقَدمة}

في خضم الجدل العالمي في شتى المجالات الديني والفلسفي والاجتماعي والاقتصادي، تولدت أهمية مناهج الجدل والأسسس التي تقوم عليها، وذلك للوصول للحقائق اليقينية في شتى المجالات، وتقليل الهوة بين المختصمين، وما الصراع العالمي اليوم في شتى المجالات إلا بسبب تمركز كل ابحاه وأيدلوجيا بمنهجية وقواعد مختلفة عن الآخر، من هنا جاءت الحاجة للرجوع للمنهج القرآي وقواعده وأسسه في الجلدل لما يملك من مؤهلات على مستوى المنهج والمادة العلمية لحل الإشكاليات العالقة والملحة، كذلك لا يمكن إغفال دور المناهج الفلسفية العالمية في المحاولة لوضوع قواعد للجدل الإنساني، والوصول إلى عمق الخقائق ويقينيتها، فراحت السفسطائية مثلا ومن خلال البيئة التي نشأت بها إلى ممارسة الجلدل الاجتماعي والقضائي والسياسي وحتى الديني أحيانا، لاظهار القدرة على محاججة الخصم ودحض أدلته، وكذلك فعلت الديالكتيك في تفسير الجدل في الواقع وانعكاسه على وحلى الأفكار فبنت منهجاً قائما على ديمومة الصراع الجلدلي للوصول إلى الحقيقة اليقينية، ويا ليتها فعلت فأصبحت الحقيقة عند السفسطائيين شكاً، وعند الديالكتيك صراعا مطلقاً في

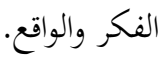


كذلك تأتي الحاجة للجدل القرآي لاستخدامه في الدعوة إلى الدين الحق وإقامة الحجة على الخلق. والحاجة بشكل أخص مع أولئك الذين نحتاج ممارسة الجدل معهمم، واستخدام الحكمة والموعظة الحسنة. والخالق سبحانه يعلم أن من الناس من يبقى متردداً، أو متشككاً في الحق الذي جاءت به النبوة الخاتمة، أو أنه يكون معانداً جاحداً له؛ مع وضوح دلائله وصفاء مصادره، فهذا نحتاج بيان أصول الجدل للتعامل معهم. أما شكل هذا الجدل-القرآين- وصفته فهو ليس بالجدل الذي قعد له اليونان، أو لهان مارسه وفق هواه وشهوته أي إنسان، وإنما هو شكل مختلف وإن تشاهت الأشكال، ووصف معين وإن تقاربت الأسماء، إنه باختصار، وكما عبر عنه كتاب ربنا جل شأنه بأوجز لفظ وأجزل عبارة (بالتي هي أحسن)، وذلك في قوله تعالى: ادْعُ ٍِالى سَبِيل رَبِّكَ بِالِِْكْمَةِ

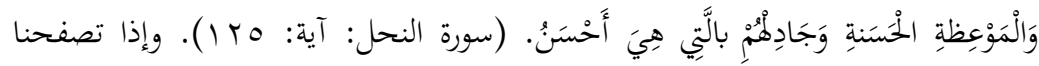
القرآن الكريم وقرأناه وجدنا فيه المناهج والقواعد المتعلقه بالمجادلات التي دارت بين أشخاص، وأمم وأفكاروخير وشر ودون ذلك كثير، وكلها لأجل بيان المنهج القرآي العظيم في ممارسة منهج الجدل مع الآخر.

\section{مفهوم الجدل في اللغة والاصطلاح}

الجدل لغة: قال ابن منظور: "الجدل: هو شدة الفتل، وجدلت الحبل أجدله جدلا إذا شددت فتله، وفتله فتلا محكما، ومنه قيل لزمام الناقة: الجديل،،'. وفي الصحاح: الجدل العضو والأجدل الصقر وجادله خاصمه بجادلة وجدالا والاسم الجدل وهو شدة الخصومة 'وقال ابن منظور: "الجدل: الصقر، صنعة غالبة، وأصله من الجدل الذي هو الشدة،"r وقال ـ أيضا . : "والجدل: اللدد في الخصومة والقدرة عليها، ورجل جدل، إذا كان أقوى في الخصام، والجدل: مقابلة الحجة بالحجة، والمجادلة: المناظرة والمخاصمة،؛؛

Muḥammad bin Mukarram al-Afrīqī al-Miṣr Ibn Manẓūr, Lisān al-'Arab (Beirut: Dār al-Ṣādir, n.d.), 11:113.

2 Muḥammad bin Ab̄̄ Bakr bin 'Abd al-Qādir al-Rāzī, Mukhtār al-Ṣiḥah, taḥqīq: Maḥmūẹ Khāṭir (Beirut: Maktabah Lubnān Nāshirūn, 1995), 14.

3 Ibn Manẓūr, Lisān al- 'Arab, 11:104

4 Ibn Manẓūr, Lisān al- 'Arab, 11:105. 
ويلاحظ أن مادة جدل في اللغة تدل على الشدة والقوة، كما تدل على المفاوضة بين الطرفين على سبيل المنازعة والمغالبة، مثلهما كمثل المصارعين، لا يزال كلاهما بصاحبه يعالج مقاومته حتى ينتصر عليه، ويلقي به على الأرض واهنًا مخذولاً. ويخلص من كلام اللغويين في معنى الجمادلة، أها مراجعة الكلام والاسترسال فيه، بقصد إفحام الخصم وإلزامه بما يريده المجادل.

الجدل في الاصطلاح: أما الجدل من حيث هو علم، فقد عرفه بعض العلماء بأنه

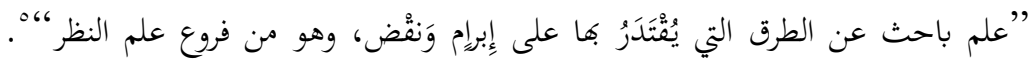

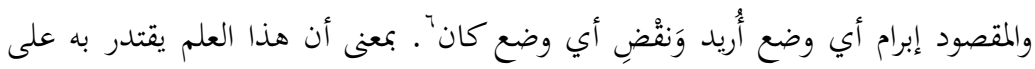
حفظ أي وضع يريده المجادل، حتى ولو كان باطلا، وهدم أي وضع يريد هدمه، حتى ولو كان حقا. قال النووي ـ رحمه الله تعالى : "الجدل والجدال والبجادلة: مقابلة الحجة بالحجة، وتكون بحق وباطل، وأصله: الخصومة الشديدة، ويسمى جدلا؛ لأن كل واحد منهما يهكم خصومته وحجته إحكاما بليغا على قدر طاقته تشبها بجدل الحبل ، وهو إحكام فتله، ل، ل. وعرفه حبنكة: "حوار كلامي يتفهم فيه كل طرف من الفريقين المتجادلين وجهة نظر الآخر، ويعرض فيه كل طرف منها أدلته، التي رجحت لديه استمساكه بوجهة نظره ثم يأخذ بتبصر الحقيقة من خلال الانتقادات التي يوجهها الطرف الآخر لأدلته، أو من خلال

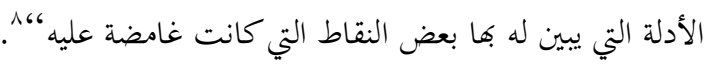
هذا هو تعريف الجدل عند العلماء. ويظهر في هذه التعريفات أثر المعنى اللغوي للجدل، فقد سبق أن الجدل هو المفاوضة على سبيل المنازعة، ولا شك أن كلا المتفاوضين يعرض أدلته التي ترجح رأيه وتدعمه، ويحاول أن يظهر معتقده بأية وسيلة كانت، ليثني صاحبه عن رأيه، ويفحمه ويلزمه بما يريد.

5 Mușțafā bin 'Abd Allāh al-Qasțanțīnī, Kashf al-Zunūn 'an Asāmī al-Kutub wa al-Funūn (Beirut: Dār al-Kutub al-'Ilmiyyah, 1992), 579.

6 Șiddīq bin Hasan al-Qinnawji, taḥqīq: 'Abd al-Jabbār Zakār, Abjad al-'Ulūm al-Washī al-Marqūm fì Bayān Aḥwāl al-'Ulūm (Beirut: Dār Al-Kutub al'Ilmiyyah, 1978), 2:208.

7 Yahyā bin Sharaf al-Nawāwī, Tahdhīb al-Asmā' wa al-Lughāt (al-Qāhirah: Dar al-Tibā'ah al-Muniriyyah, n.d.), 3:48.

8 'Abd al-Raḥman Hasan Habannakah al-Maydānī, Dawābit al-Ma'rifah wa Ușūl al-Istidlāl wa al-Munāzarah (Damsyik: Dār al-Qalam, 2008), 361. 
كما أنه يبدو من التعريفين الأولين، أفم يعممونه على المجادلة على الحق أو الباطل

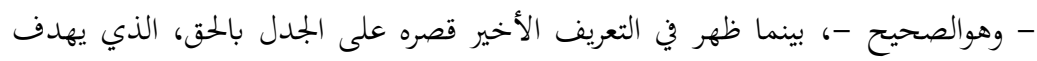
للوصول إلى الحقيقة والصواب.

الجحل بين القرآن والعقل الغربي من السفسطائية إلى الديالكتيك

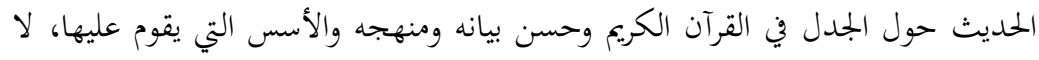

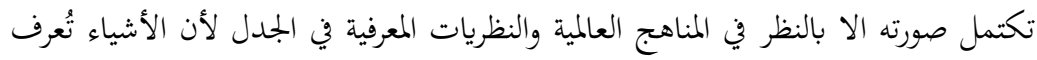

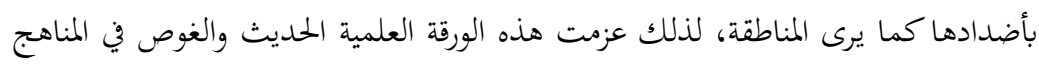

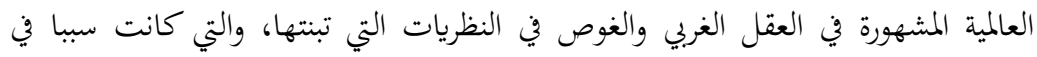

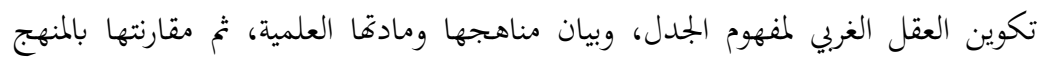

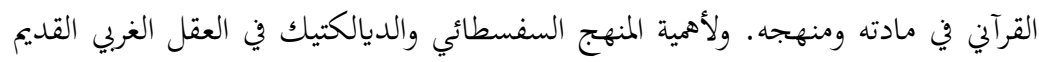

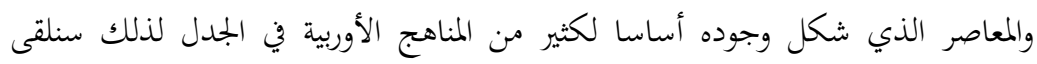
الضوء على ملامح هذه المناهج والبعد الفلسفي الذي قامت عليه ومقارنته بالمنهج القرآين.

| (الجحدل السفسطائي إن الحديث حول الجدل في التراث اليوناني لا تكتمل صورته بدون الحديث حول الجدل الجدل

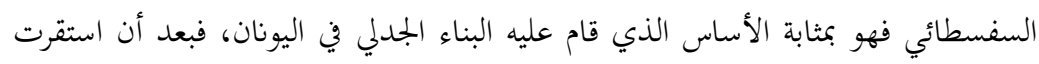

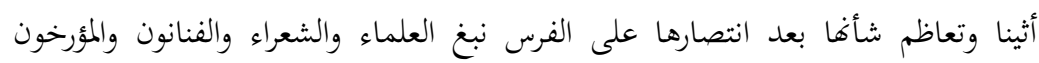
والأطباء والصّناع وقوية الديمقراطية، وتعاظم التنافس والتنازع بين الافراد امام المحاكم والمجالس، وشاع الجدل القضائي والسياسي فنشأت من هاتين الناحيتين الحاجة إلى تعلم الجدل ووسائله فنشأت السفسطائية".

9 Yūsuf Karam, Tarīkh al-Falsafah al-Yūnāniyyah (Beirut: Dār al-Qalam, n.d.), 33. 


$$
\begin{aligned}
& \text { والسؤال الذي يطرح نفسه ما هي الأسس الفلسفية والغايات التي قام عليها الجلدل } \\
& \text { السفسطائي؟ نستطيع القول بأن أبرز ملامح هذا الجدل قيامه علي مبدأ الشكبـ } \\
& \text { والاسطورة، فشكك الجدل السفسطائي في حقائق الأشياء والقيم وامتد عبثه الي المبادئ } \\
& \text { الخلقية والاجتماعية، ومن أبرز الآراء التي اعتمدوا عليها في مذهبهم مقولة ”بروتاغوراس، } \\
& \text { ين كتابه (عن الحقيقة): إن الإنسان مقياس كل شيء، فهو مقياس وجود الموجود منها } \\
& \text { ومقياس لا وجود غير الموجد منها "وقد شرحها افلاطون في محاوراته أن مؤداها: إن } \\
& \text { الأشياء هي بالنسبة لي هي ما تبدو لي، وهي بالنسبة إليك هي ما تبدو إليك وأنت إنسان } \\
& \text { وأنا إنسان، فالمقصود بالإنسان هنا الفرد من حيث هو كذلك، لا الحقيقة الموضوعية، ولما } \\
& \text { كان الأفراد يختلفون سنا وتكوينا وشعورا وكانت الأشياء تتنلف وتتغير، كانت } \\
& \text { الإحساسات متعددة بالضرورة ومتعارضة، اليس هواءً بعينه يرتعش منه الواحد ولا يرتعش } \\
& \text { منه الآخر، ويكون خفيفا على الواحد عنيفاً على الآخر، إذاً فلا يوجد هو واحد في ذاته } \\
& \text { وبذاته، ولا يوجد شيء يمكن أن يسمى او ان يوصف بالضبط لأن كل شيء في تحول } \\
& \text { مستمر،،'ا'. فهذا هو البعد الفلسفي الذي ينطلق منه الجدل عند السفسطائين والعقل } \\
& \text { اليوناني في تلك المرحلة. }
\end{aligned}
$$

10 Al-Shakku huwa al-taraddud bayna naqidayn lā yurajjiḥu al-‘aqal aḥadahumā 'alā al-akhar, wa dhālika li wujūdi āmārāt mutasāwiyah fĩ al-ḥukmayn, aw li 'adami wujūd ayyat amārah fïhimā, wa yarji'u turaddud al-'aql bayna alḥukmayn ilā 'ajzihi 'an mu'ānāh al-taḥlīl aw ilā qanā'atihi bi al-jahl. Walakin al-shakku alladhī na`nihi hunā mukhtalif fa huwa al-shakku fì haqā'iq alashyā' muṭlaqan wa yusammīhī Dīkārt al-shakku al-mufarriṭ ayy al-shakku almanhajī al-shāmil alladhī yamtaddu ilā kulli shay'. Unzūr Jamīl Șalibā, alMu 'jam al-Falsafí (Lubnān: Dār al-Kutub al-Lubnāniyyah, 1982), 1:705.

11 Unzūur Afalāțūn, Muḥāwarah Thiyātitūṣ li Afălațūn aw 'an al-'Ilm, tarjamah: Amīr Ḥilmī (al-Qāḥirah: Dār al-Gharīb li al-Nashr, 2000), 39. 
السامعين على اعتبار أن الخطابة تعتمد على زخرفة القول والألفاظ البراقة أكثر من اعتمادها على العقل وحججه المنطقية' 'ال. ويصف أفلاطون منهج السفسطائية القائم على الزخرفة والاستعراض البلاغي والبياني وأنه غاية عند السفسطائيين ويضيف استخدامهم للأسطورة لجذب التلاميذ يقول "ونلاحظ وجود تنافس بين السفسطائيين الثلاثة على جذب الأنظار إليهم، يعني تلاميذ جدداً وحظاً أوفر من الأجر، وهم من أجل هذا يستخدمون كل ألوان الدعاية الممكنة، ويشبهون بالفعل“" وهكذا يصورهم افلاطون "أفم كالتجار الذين يعرفون كيف يعرضون سلعهم في الأسواق، ويبرزون عضلاهم ليجتمع من حولمم المشاهدون، وعضلات السفسطائيين من كلمات، واذرعتهم من الألسن وساحاقم هي ساحات النقاث،

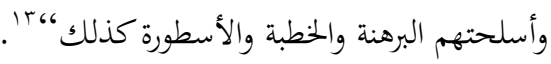

وذهبت المدرسة السفسطائية بمفهوم الجدل أكبر من ذلك لمناقشة المغالطات السفسطائية، كأغلوطة" الكذب،" التي تنسب إلى ” أربليس “، ومفادها إن الإنسان إذا كذب وقال إني كاذب فهو صادق إم كاذب، وإذا كان الجواب إنه صادق فكيف كذب إذا؟ وإذا كان الجواب إنه كاذب فماذا عن اعترافه بالكذب، وكيف يمكن ان يكون بالتالي صادقا وكاذباً في آنٍ معا، وغيرها من الأغاليط السفسطائية التي انتشرت في المنهج الجدلي ؛' . إذن فنحن على مستوى جدل لغاية الجدل ذاته، فالبعد الفلسفي للجدل عند السفسطائيين هو عدم وجود الحقيقة الواحدة وان الحقيقة نسبية وتختلف بين شخص وآخر، ولعلنا نتساءل هنا ما الفائدة للجدل بهذا المعنى السفسطائي الذي مارسته المدرسة اليونانية.

12 Unẓūr Faḍl Allāh Mahdī, Madkhal ilā 'Ilm al-Manṭiq ('Ilm al-Manțiq alTaqlīdī) (Beirut: Dār al-Ṭalī'ah, n.d.), 3:15.

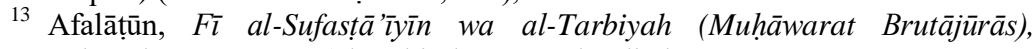
tarjamah 'Izzat Qarnī (al-Qāhirah: Dār Qubā' li al-Nashr, 2001), 24.

14 Unzūr Afalātūn, Fì al-Sufastāà'yȳ̄n wa al-Tarbiyyah, li al-Istizadati unẓūr kadhālik: La'asākir Yusuf, “Al-Jadal fì al-Qur'ān Khașā'ișuhu wa Dalālātuhu "Jīdāl ba'ḍ̄ā al-Anbiyā̄" Namūdhajan Dirāsah lughwiyah delāliyah (Risālah Mājistīr, Wizārah al-Ta' līm al-Ālī wa al-Baḥth al-'Ilmī, Jāmi'ah al-Jazā'ir, 2000), 73 . 
ونلاحظ ومن خلال ما سبق ان الجدل السفسطائي يميل إلى الجانب الخطابي والزخرفي والبلاغي لمذه المماحكات فكان غالبا على مفهوم الجدل الترف في صياغة الأدلة، بدليل اهم يتفاخرون بتأييد القول الواحد ونقيضه على السواء وبإيراد الحجج الحلابة في مختلف المسائل والمواقف، ولم يكن غرضهم تغيير النظر في الألفاظ ودلالاتما، والقضايا وانواعها والحجج وشروطها، والمغالطات وأساليبها ل.

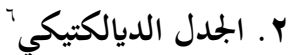

إذا عرفنا الجدل بأنه فن البرهان وفن دحض كلام الخصم، لأن المجادل يدري كيف ينظم معرفته فيضعها في نظام متماسك كما يعرف بصفة خاصة كيف يجد أساساً منطقيا لآرائه، كما ان المجادل يتميز على نهو خاص ببراعته في تمييز الصحيح من الفاسد فيما يعرفه الآخرون من آراء كما يتميز أيضا بمقدرته على استكشاف موطن الضعف في نظرية الخصم وإدلائه بالحجج القطاعة التي تستطيع أن بحبر المعترض على السكوت لأ. فالجدل اذن عبارة عن فن صوغ المحاكمات المتماسكة والدقيقة وجعلها تتسلسل بصورة محكمة،،'1، . فنلاحظ أن الجدل هنا وبهذا المفهوم وثيق الصلاة بالمنطق غير ان هذه الكلمة، كلمة منطق أحرى بأن تدل على نظرية التفكير العقلي في حين الجدل يقوم على فن تطبيق معرفتنا بالقواعد المنطقية على سياق المناقشة' 19 أما الديالكتيك الذي نحن بصدد فهمه فيعرف بأنه "درس التناقضات في ماهية الأشياء ذاتما،بr فنقطة الابتداء في الديالكتيك هي وجهة النظر القائمة على أن كل أشياء

15 Unẓūr, Yūsuf Karam, Tarīkh al-Falsafah al-Yūnāniyyah, 33.

16 Dars al-Tanāquḍāt fĩ māhiyah al-ashyā' dhātihā fanuqțah al-ibtidā'i fì aldiyāliktīk hiya wijhah al-naẓar al-qā'imah'alā anna kulla ashyā' al-țabī'ah wa ḥāwādithuhā taḥwī tanāqựāa dākhiliyah wa ta'īshu jadālan mustamiran li anna lahā jamī'an jāniban salbiyyan wa jāniban ījābiyyan māḍiyyan wa ḥāḍian wa fỉhā jamī' 'awāmil tațawwūr wa tuḥawwil, wa huwa al-muhtawā al-dākhilī li ḥarakati al-tațawwūr. Unzūur: Stalīn, al-Māddiyyah al-Diyāliktikiyyah wa alMāddiyyah al-Tārīkhiyyah (n.p.: Dār Damsyik, n.d.), 2.

17 Fatḥ al-Raḥman al-Ja' 'Tì, Al-Îmān bi Allāh wa al-Jadal al-Shuyū' ‘̀ (Jeddah: Dār al-Su'ūdiyyah li a;-Nashr, 1984), 1:17.

18 Al-Ja'lī, Al-İmān bi Allāh wa al-Jadal al-Shuȳu '̄̄, 18.

19 Mukhtār 'Ațā Allāḥ wa ākharun, Nazariyyah al-Ma'rifah ta'ṣiluhā wa Ittijāhātuhā (Riyadh: Dār Madār al-Wațan, 2017), 2:35. 
الطبيعة وحوادثها تحوي تناقضات داخلية وتعيش جدلاً مستمرا لأن لما جميعا جانباً سلبياً وجانباً ايجابياً ماضيا وحاضرا وفيها جميع عوامل تطور وتحول، وهو المحتوى الداخلي لحركة

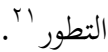

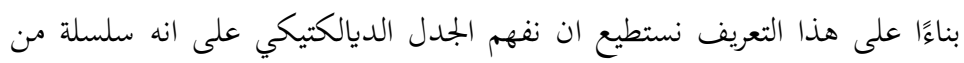

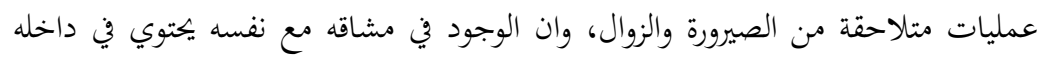

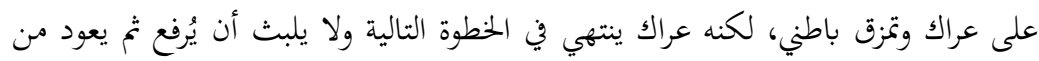
جديد وهكذا باستمرار.

بل ان هذا الجدل في المفهوم الديالكتيكي لا يقتصر على الجانب الواقعي بل يتعدى لئل

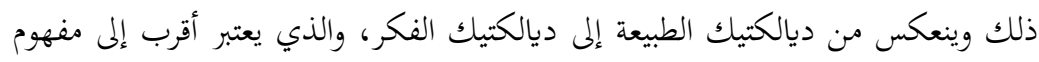

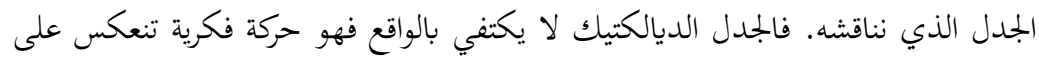

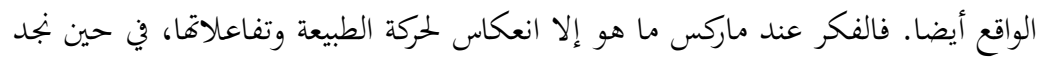

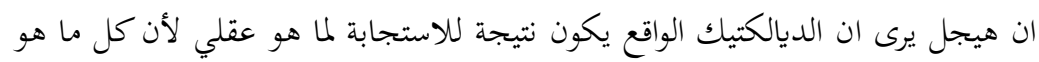
عقلي واقعي وكل ما هو واقعي عقلي. يقول انجلز شارحا الديالكتيك الماركسي "فلو أعدنا النظر إلى فكر دماغنا من وجهة

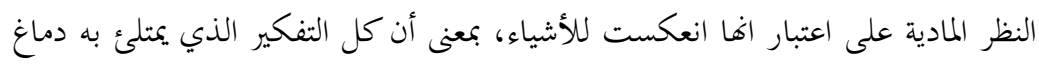

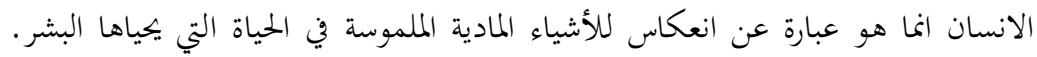

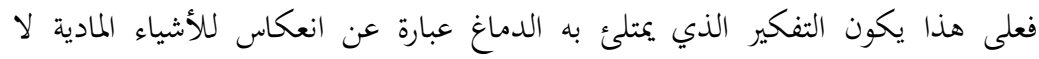

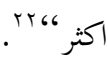
اذن نحن امام جدل من الواقع إلى الفكر عند هيجل وينتقل من الفكر إلى الواقع

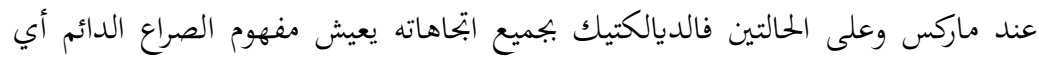

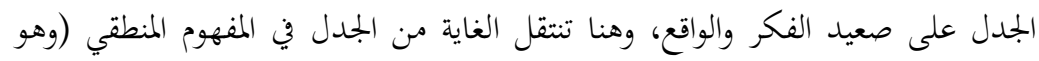

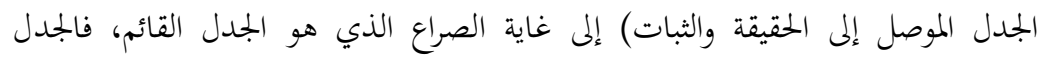

${ }^{20}$ Stalīn, al-Māddiyyah al-Diyāiktikiyyah wa al-Māddiyyah al-Tārīkhiyyah, 2.

${ }^{21}$ Stalīn, al-Māddiyyah al-Diyāliktikiyyah wa al-Māddiyyah al-Tārīkhiyyah, 1213.

${ }^{22}$ Fasili Koznitsof, Ludfij Fìrubakh wa Nihayat al-Falsafah al-Kilasīkiyyah (n.p.: Dār al-Taqwīm, al-Ittiḥād al-Sufyitī, 1978), 84. 
الديالكتيك لا ينتهي مطلقاً، ولا يصل إلى نتيجة فهو صراع مستمر وذروته غاية الجدل،

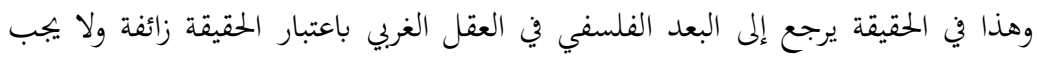

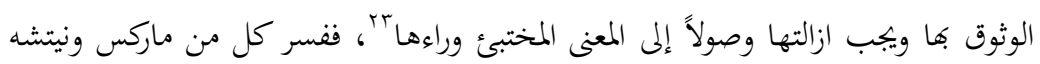

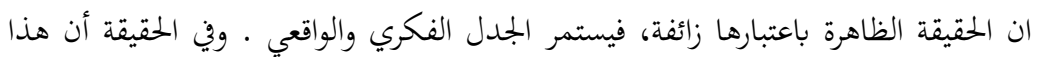

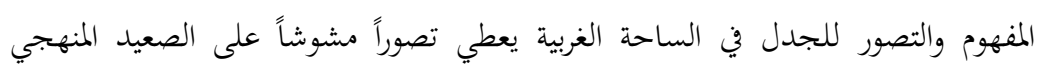

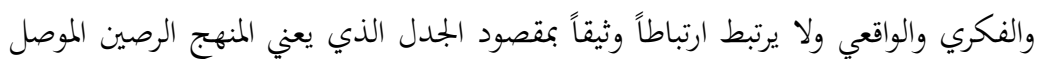

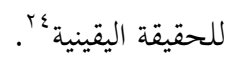

\section{r. الجدل القرآي في ضوء الجدل السفسطائي والديالكتيك}

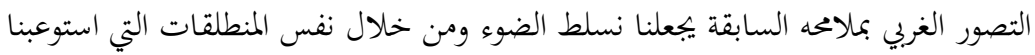
مها ومن خلالها الجدل الغربي المرتبط بالديالكتيك والسفسطائية للنظر في مفهوم الجدل الندل القرآي في ضوء الواقع والفكر وانعكاس كل منهما على الآخر في الفهم القرآين.

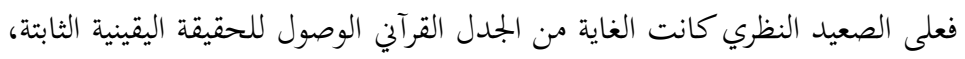

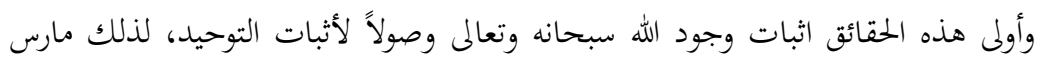

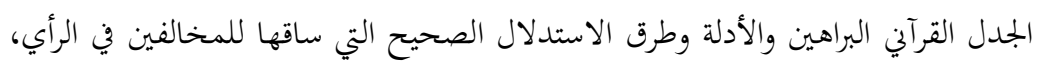

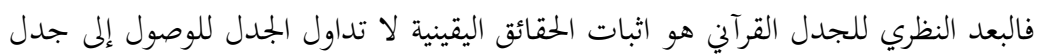

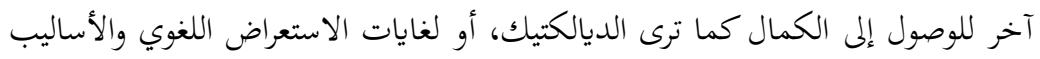

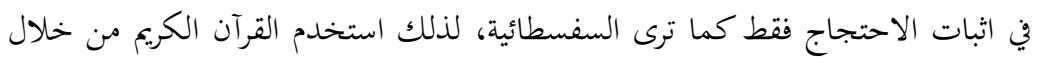

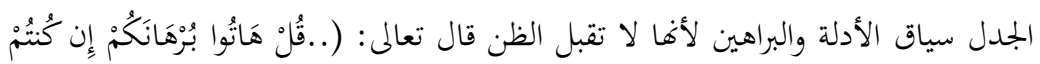

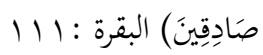

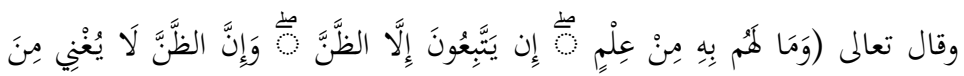

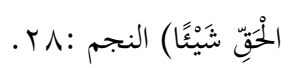

23 Thomas Ar Flin, al-Wüjūdiyyah, tarjamah Marwah 'Abd al-Salām (alQāhirah: n.p., 2014), 67.

24 Stalīn, al-Māddiyyah al-Diyāliktikiyyah wa al-Māddiyyah al-Tārīkhiyyah, 711. Unẓūr kadhālik al-Ja'lī', Al-İmān bi Allāh wa al-Jadal al-Shuyū 'ì, 17. 
فالقرآن الكريم بمنهجه العلمي استخدم الجدل للوصول للحقائق من خلال البرهان

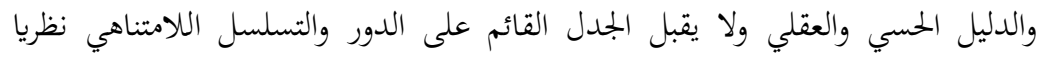
وواقعياً، فالغاية في الجدل القرآني هي الوصول لليقين، لذلك سلك الفيل القرآن كل ما ما يتصوره

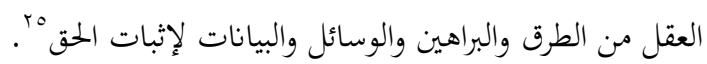

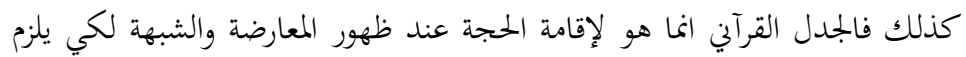
المجادل ويُفهم المعاند، فهو منهج عَارض يُستخدم حين الحاجة وليس دائم ومستمر كما تراه الديالكتيك.

كذلك ارتبط الجدل القرآني بالدليل المستلزم سلامة الفطرة خلافاً للسفسطائية

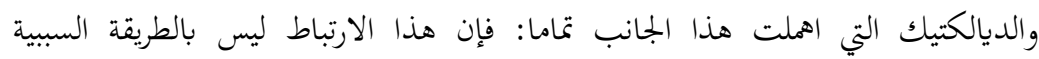

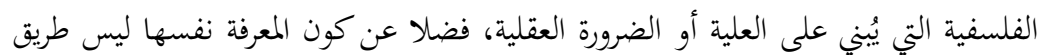

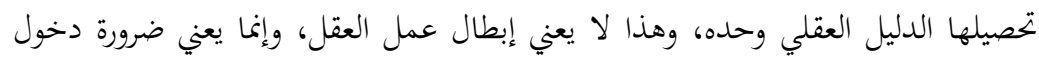

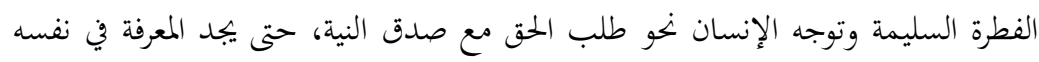

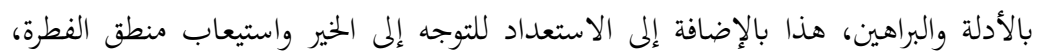

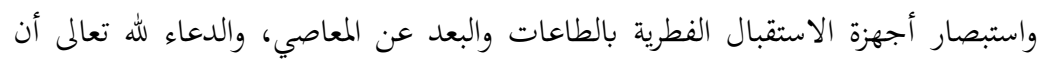
يخلق العلم في النفس بعد النظر والتأمل، فقد ينصب الدليل ولاعل ولات تحصل المعرفة، قال تعالى:

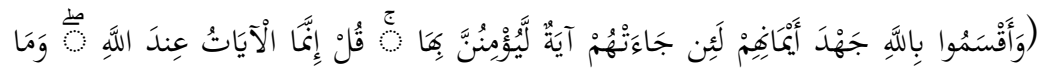

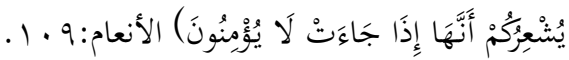
أما على الصعيد الواقعي الذي تقول به الديالكتيك فهو الجدل الدول والصراع الدائم في الكون، فإن القران الكريم يظهر الاختلاف في الكون وتعدد الأوجه فيه من اختلاف الكئ الليل والنهار والألوان وغير ذلك على انه الانسجام التام للحقيقة المطلقة الموصلة للتوحيد قال

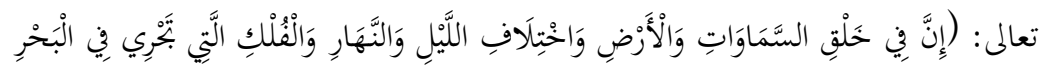

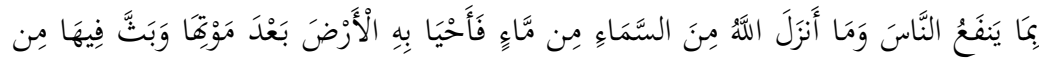

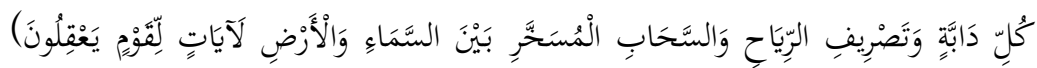

25 Al-Alma‘ī, Manāhij al-Jadal fì al-Qur’an al-Karīm (Riyadh: Mațā’bi‘ alFarazdaq, n.d.), 2. 
البقرة: ـ1 ا فهذا الخلق السابح هو تحت منظومة الانسجام ولا بجال للصراع والجدل المطلق وهذا التوازن دليل على ذلك .

ومن جانب آخر استطاع الجدل القرآني توجيه العقل في الجانب الغيبي (الميتافيزيقي)،

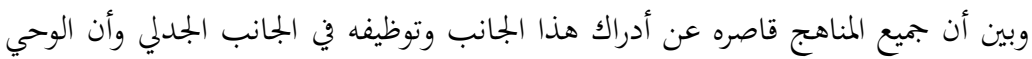

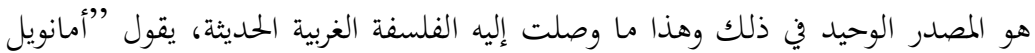

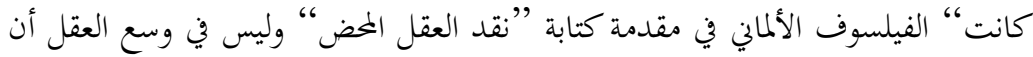
يقدم إجابات شافيه في مسائل الميتافيزيقيا، وخلق العالم والروح لأن قدرته كلها دون

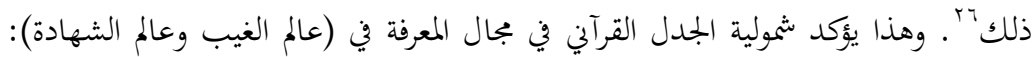
فمجال عالم الشهادة هو الإيمان بالمسوس فجاء الجدل القرآي يتطرق إلى هذا الجانب ويشبعه من الناحية الاستدلالية، وكذلك جاء الجدل القرآي وغذى المجال الغبي هو الإيمان بالا حسوس، الذي افتقرت إلية المناهج الغربية القديمة والمعاصرة.

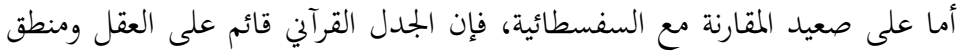
الحجة والبلاغة والبيان في آن واحد وهو استدلال يقوم على مقدمات وعرض ونتائج، بل

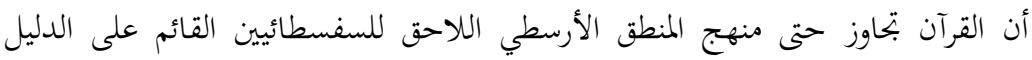

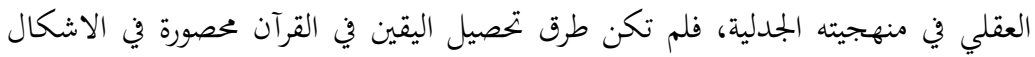

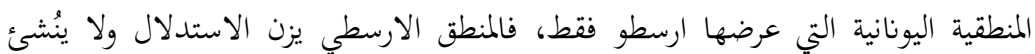

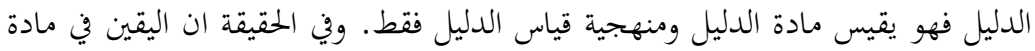

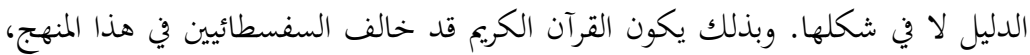
وتفوق على المنطق الارسطي كذلك في تعدد صور الاستدلال، وكذلك في انشاء المادة

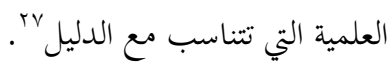
فيؤكد القرآن على الاستدلال اليقيني، وجعله معيار في الحكم على القضايا ويرفض

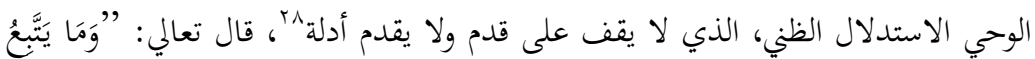

${ }^{26}$ Unzūr Ahmad 'Abd al-Raḥman, Dawābit al-Ma 'rifah fi al-Qur'ān, 115.

${ }^{27}$ Unzūr Yusūf La' 'asākir, "Al-Jadal fì al-Qur'ān Khașā' iṣuhu wa Dilālāthi "Jadāl ba đ̣̣a al-Anbiyā”” Namūdhajan Dirāsah Lughwiyyah Dalāliyyah, 73.

${ }^{28}$ Mukhtār 'Ațā Allāḥ wa ākharun, Nazariyyah al-Ma'rifah ta'ṣiluhā wa Ittijāhātuhā, 2:35. 


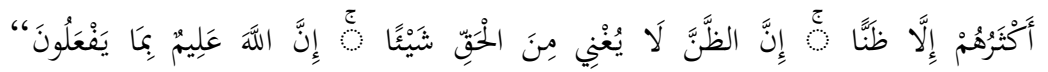

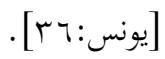

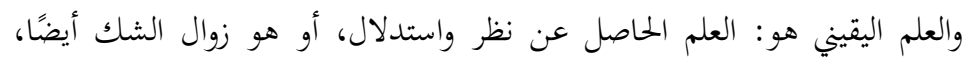

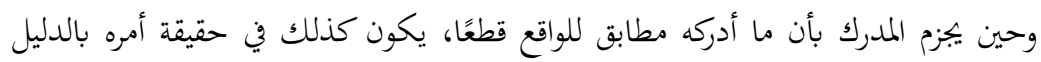
القاطع فإن جزمه هذا هو ما يسمى باسم 》اليقين《 خلافا للسفسطائية.

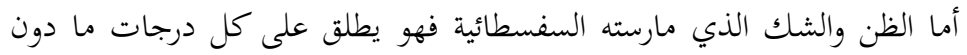

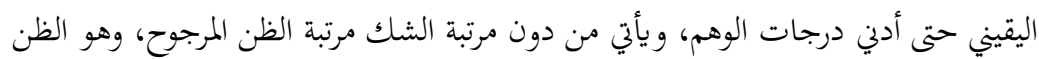

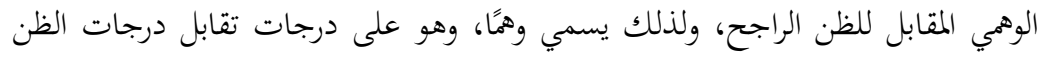

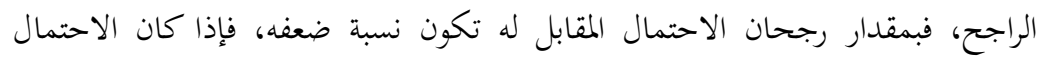

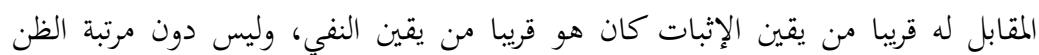

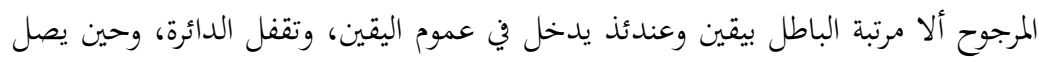

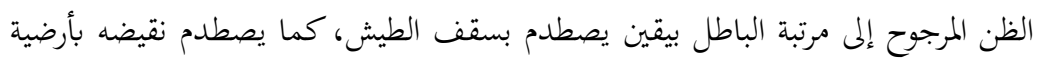

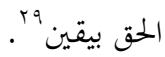

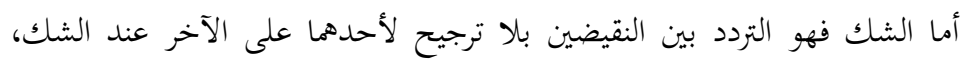

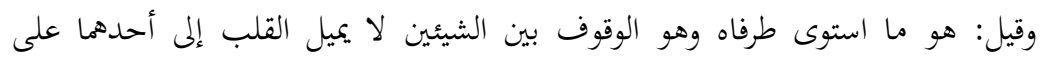

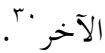

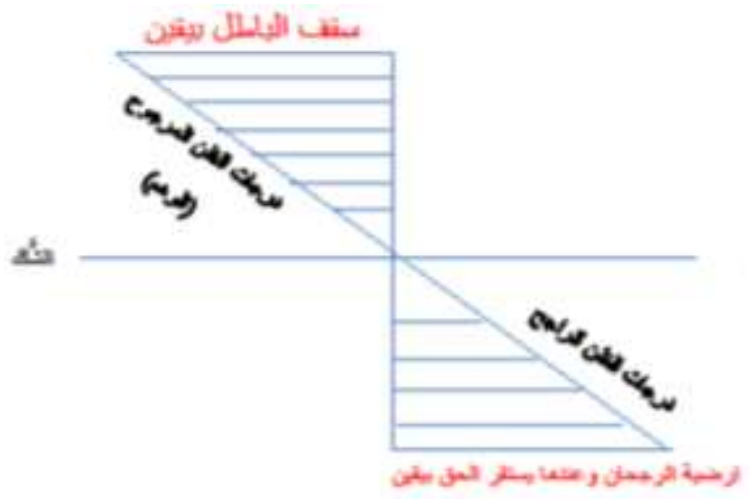

${ }^{29}$ Hasan Habannakah, Dawābiț al-Ma'rifah wa Ușūl al-Istidlāl wa alManāzirah, 126.

30 Unẓūr Jamīl Șalibā, al-Mu 'jam al-Falsafì, 705. 
كذلك نلاحظ أن القرآن الكريم لم يسلك مسلك السفسطائيين فخفف من

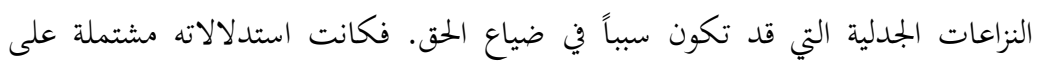

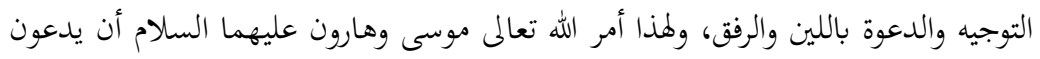

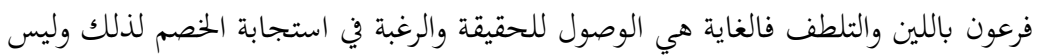

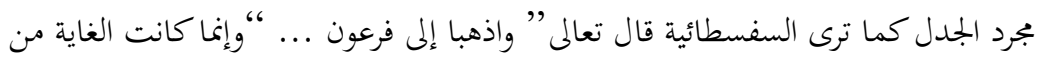
الجدل وإقامة الحجة والبرهان عند ظهور المعارضات والشبه لكي يلزم البمادل ويفحم المعاند والمكابر.

ومن أعظم المسائل التي يعتمدها القرآن الكريم في الجدل خلافا للسفسطائية

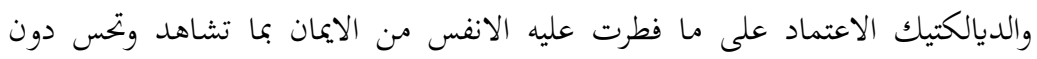

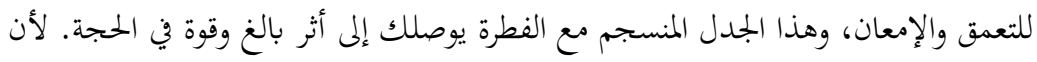

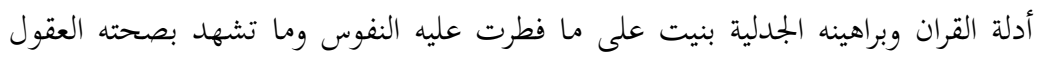

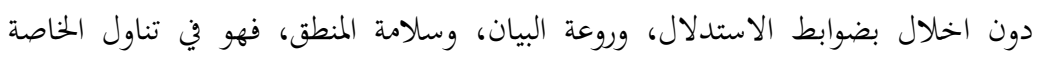

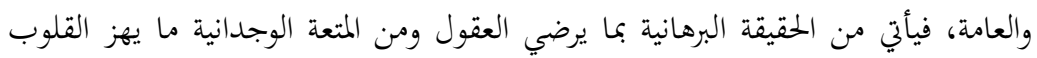

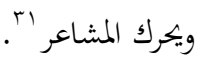

وكذلك لا يمكن أن نتجاهل من خلال هذه المقارنة البعد الأخلاقي والقيمي الذي مارسه القرآن والفكر الإسلامي للجدل ومنهج ممارسته مع الاخر خلافاً للسفسطائية والديالكتيك، التي مارست ارغام الخصم على قبول الرأي دون الاهتمام في المنهج

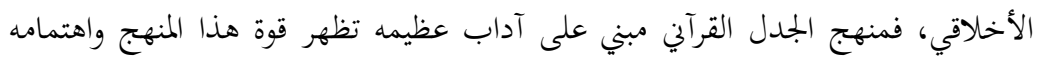

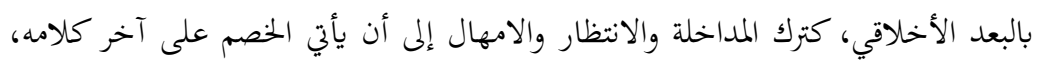

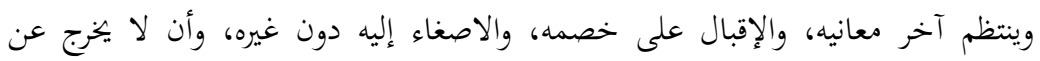

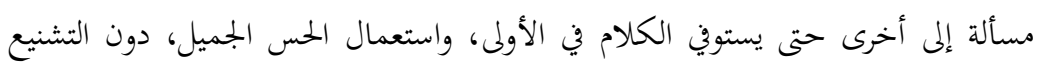

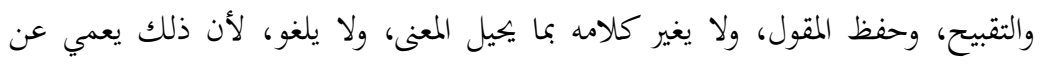

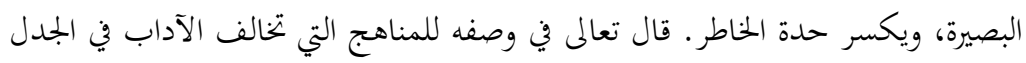

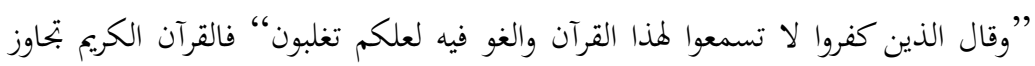

31 Al-Alma‘̄i, Manāhij al-Jadal fì al-Qur’an al-Karīm, 98. 
المناهج الآنفة الذكر إلى ممارسة القيم والآداب في الجمادلة والحوار، وهذا يعطي عمقاً،

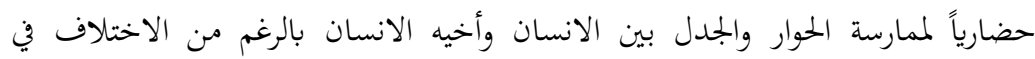

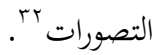

\section{نماذج الجدال العلمي والحلقي في القرآن}

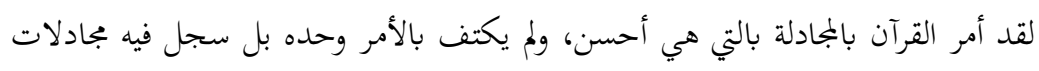

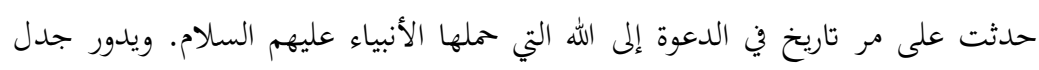

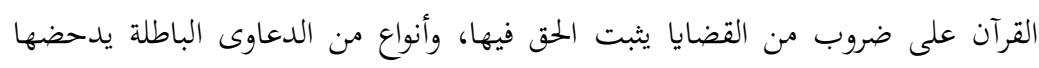

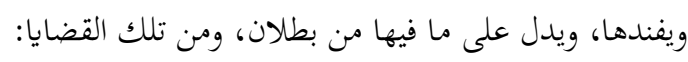

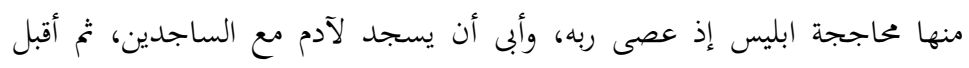

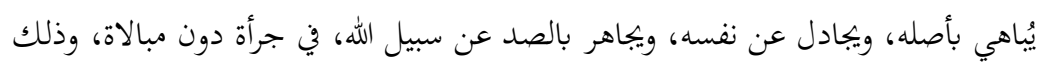

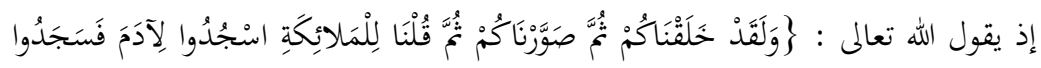

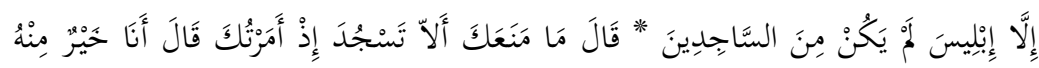

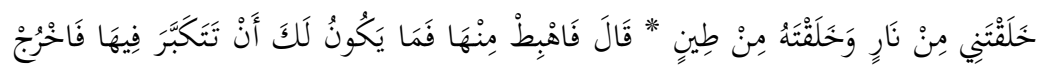

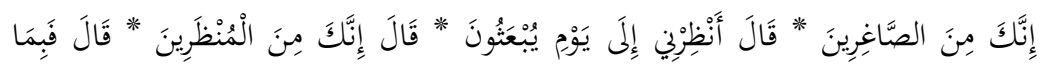

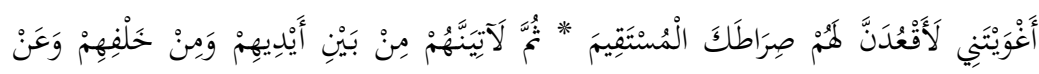

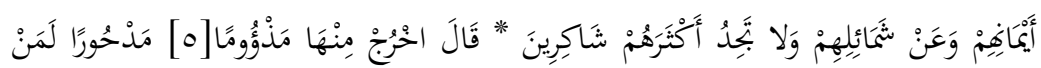

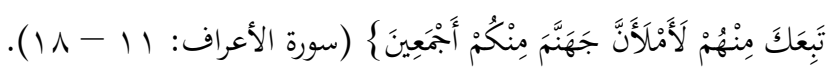

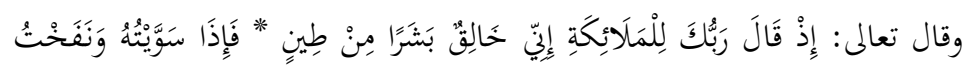

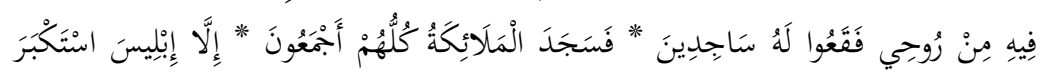

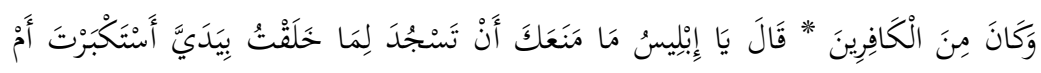

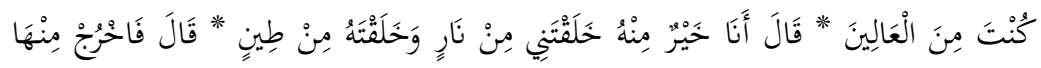

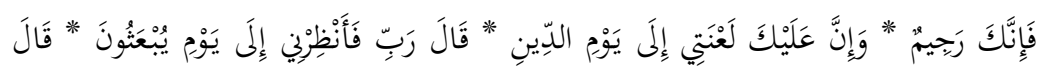

32 Abū al-Wafā' 'Alī bin 'Aqeel al-Baghdādī al-Ḥanbalī, Kitāa al-Jadal 'alā țarīqah al-Fuqahā' (al-Qāhirah: Maktabah al-Thaqāfah, n.d.), 2. 


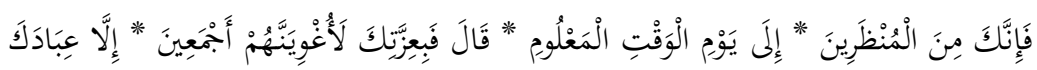

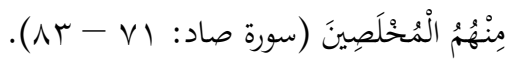

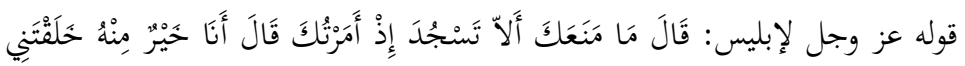

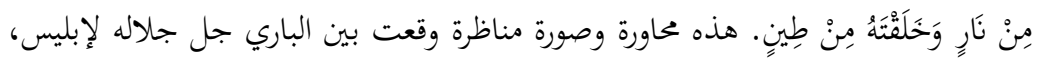

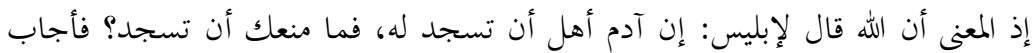

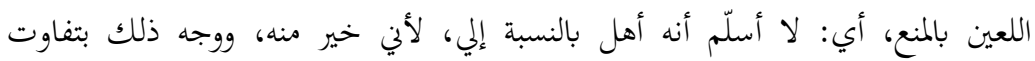

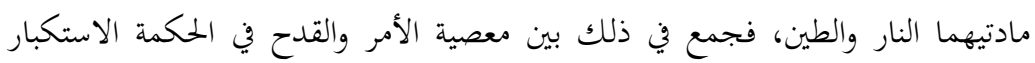
والاصرار

قال ابن عباس أول من قاسَ إبليس، فأخطأ القياس فمن قاسَ الدين بشئ من رأيه

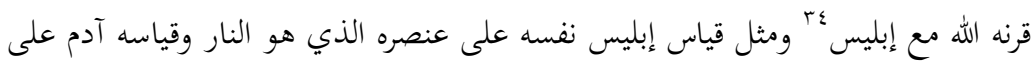

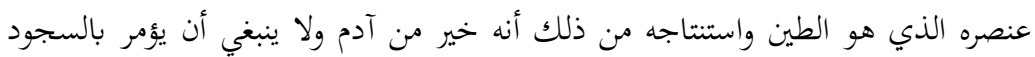

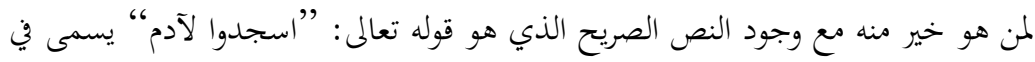

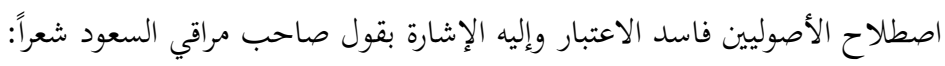

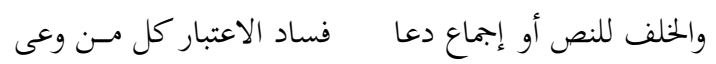
فكل من رد نصوص الوحي بالأقيسة فسلفه في ذلك إبليس وقياس إبليس هذا لعنه

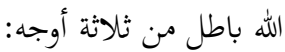

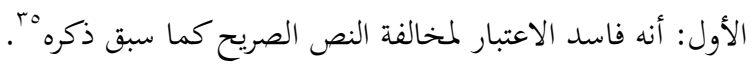

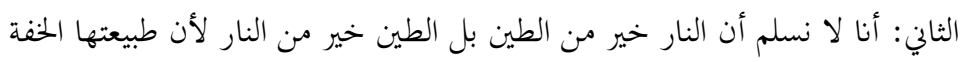

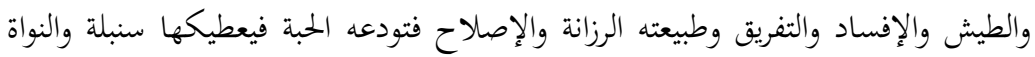

${ }^{33}$ Najm al-Dīn al-Ḥanbalī al-Ṭūfî, 'Ilm al-Jadal fì 'Ilm al-Jadal, taḥīq: Volvhart Haynrishs (Beirut: Dār al-Nashr Franz Shtaynar Pvesbadin, 1987), 121-122.

34 Abū Muḥammad al-Ḥusayn ibn Mas'ūd ibn Muḥammad al-Farrā’al-Baghawī, Tafsìr al-Baghawī, taḥqīq: Khālid 'Abd Raḥman al-'Akk (Beirut: Dār alMa'rifah, n.d.), 2: 150.

35 Muḥammad al-Āmīn bin Muhammad al-Mukhtār al-Ja'nī al-Shanqīitī, Aḍwa' al-Bayān fì Ị̇āh al-Qur'an bi Al-Qur'ān, tahqīq: Maktab al-Buhuth wa alDirāsāt (Beirut: Dār al-Fikr li al-Ṭibā'ah wa al-Nashr, n.d.), 1:33. 
فيعطيكها نخلة، وإذا أردت أن تعرف قدر الطين فانظر إلى الرياض الناضرة وما فيها من

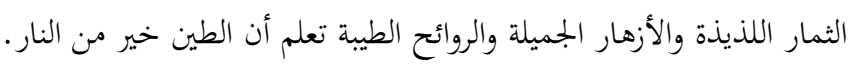

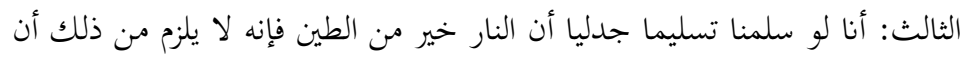

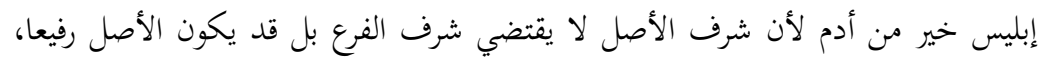

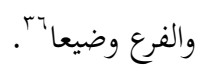

ومن الآيات التي تحاجج وبحادل اعظم مسألة في الوجود قضية الشرك بالله، واتخاذ

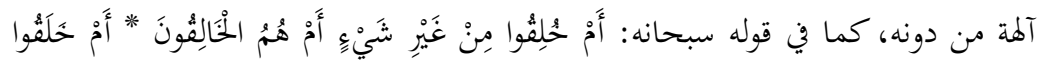

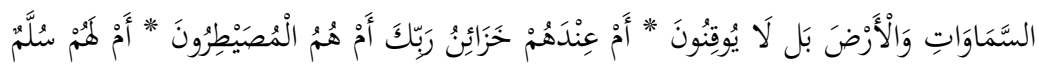

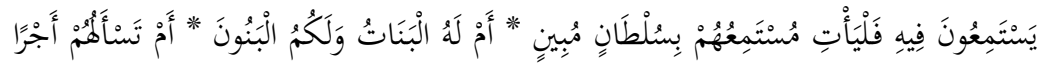

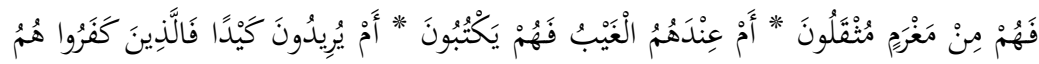

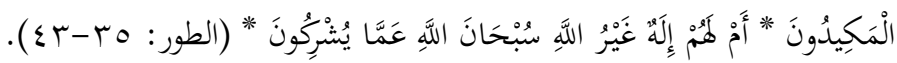

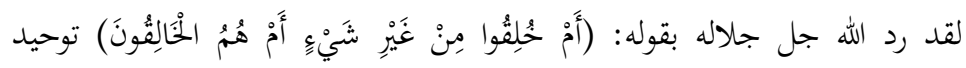

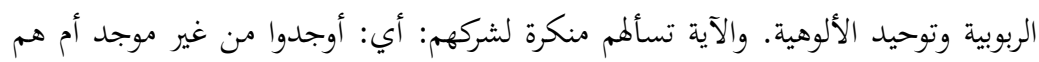

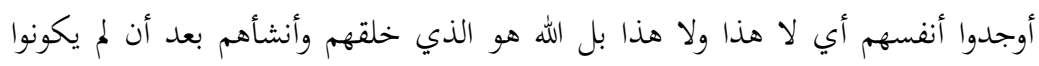

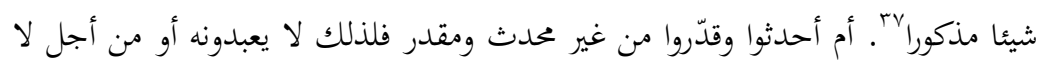

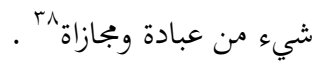
ولشدة وقعة هذه الآية وقوتا في الرد على من أشرك بالله تعالى، كانت من بين أسباب دخول جبير بن مطعم إلى الإسلام، كما ورد في صحيح البخاري، قال البخاري:

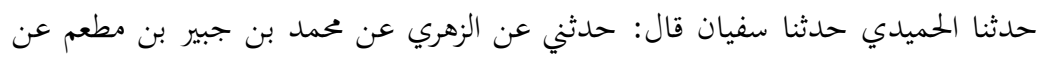

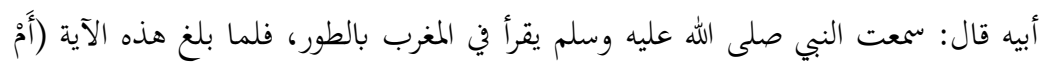

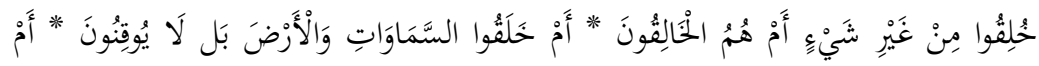

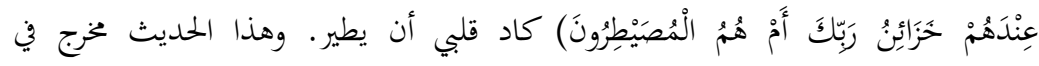
الصحيحين من طرق عن الزهري به وجبير بن مطعم كان قد قدم على النبي صلى الله عليه

36 Al-Shanqīî̄, Aḍwa' al-Bayān fì Ị̇āh al-Qur'an bi Al-Qur'ān, 1:33-34.

37 Al-Shanqīitī, Aḍwa' al-Bayān fì Ị̇āh al-Qur'an bi Al-Qur'ān, 4:245.

38 Nașr al-Dīn Abū al-Sa'īd 'Abd Allāh bin 'Umar bin Muhammad al-Shīrāzī alBayḍāwī, Tafsìr al-Bayḍ̂̄wī (Beirut: Dār al-Fikr, n.d.), 5: 249. 
وسلم بعد وقعة بدر في فداء الأسارى وكان إذ ذاك مشركا فكان سماعه هذه الآية من هذه

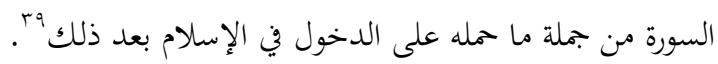

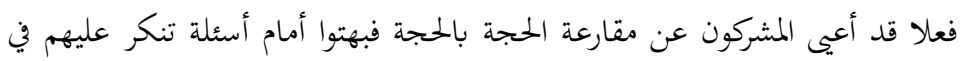

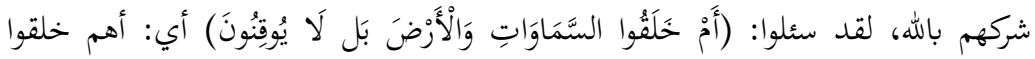

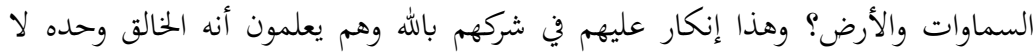

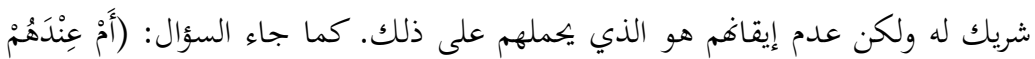

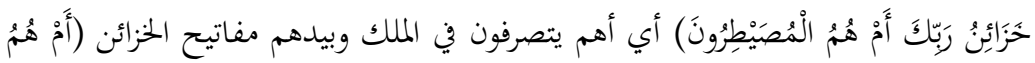

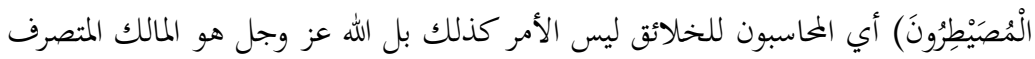
الفعال لما يريد. كذلك يأتي سؤال آخر تعجزهم عن الرد في قوله تعالى (أم لهم سلم

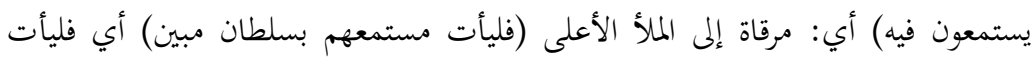

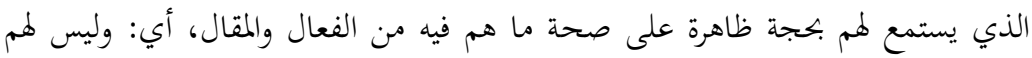

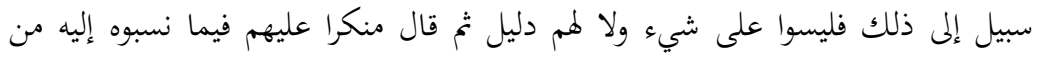

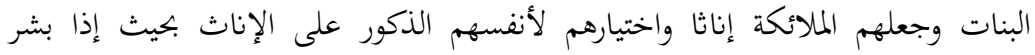

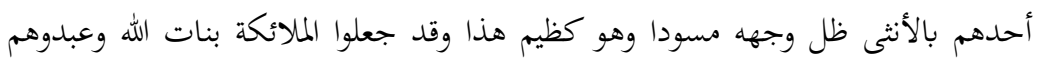

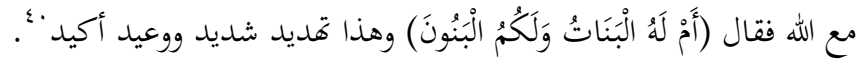

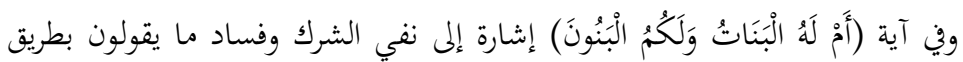

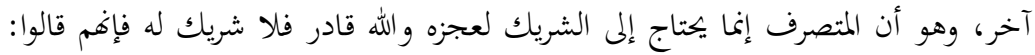

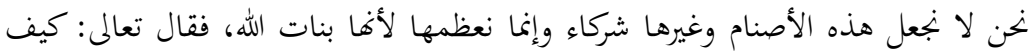

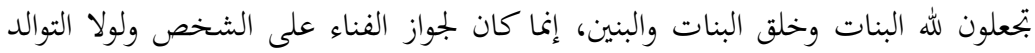

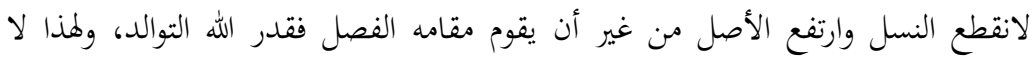

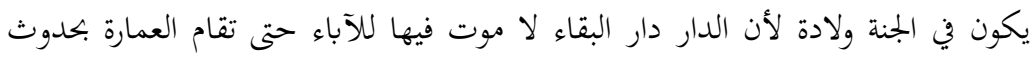

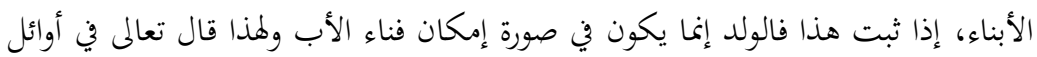

39 Ismā'īl bin Kathīr, Tafsīr al-Qur'ān al- 'Ażīm (Beirut: Dār al-Fikr, n.d.), 5: 249.

40 Ibn Kathīr, Tafsīr al-Qur'ān al- 'Ażìm, 5: 249. 
سورة آل عمران الَّْهُ الَْقَيُوُُ (آل عمران) أي حي لا يموت فيحتاج إلى ولد يرثه وهو قيوم لا يتغير ولا يضعف فيفتقر إلى ولد ليقوم مقامه لأنه ورد في نصارى نجران.

ثم إن الله تعالى بيّن هذا بأبلغ الوجوه وقال إذم يجعلون له بنات ويجعلون لأنفسهم بنين مع أن جعل البنات هم أولى وذلك لأن كثير البنات تعين على كثرة الأولاد لأن الإناث الكثيرة يمكن منهن الولادة بأولاد كثيرة من واحد وأما الذكور الكثيرة لا يمكن منهم إحبال أنثى واحدة بأولاد ألا ترى أن الغنم لا يذبح منها الإناث إلا نادراً وذلك لما ثبت أن إبقاء النوع بالأنثى أنفع نظراً إلى التكثير فقال تعالى: أنا القيوم الذي لا فناء لي ولا حاجة لي في بقاء النوع في حدوث الشخص وأنتم معرضون للموت العاجل وبقاء العالم بالإناث أكثر وتتبروون منهن و الله تعالى مستغن عن ذلك وبتعلون له البنات، وعلى هذا فما تقدم كان إشارة إلى نفي الشريك نظراً إلى أنه لابتداء لله وهذا إشارة إلى نفي الشريك نظراً إلى أنه لا فناء له 'أله

وكذلك بتح القرآن الكريم يظهر أهمية انكار التقليد والتبعية من خلال منهج الحوار والجدل المقنع لما لما أثر بالغ في اتخاذ القرار والايمان والمعتقد قضية التقليد في العقيدة،

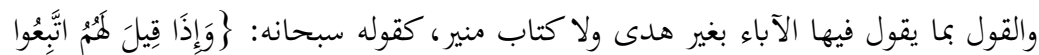

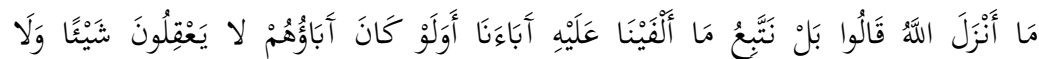
يَهْتَدُونَ \{ (البقرة: .

الآية نزلت في المشركين، أمروا باتباع القرآن وسائر ما أنزل الله تعالى من الحجج الظاهرة والبينات الباهرة فجنحوا للتقليد من اتخاذ الأنداد وتحريم الطيبات r؛؛ وإن كان

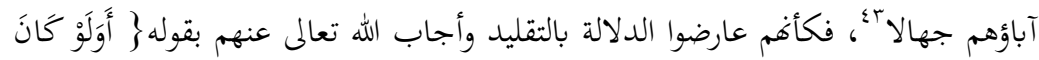

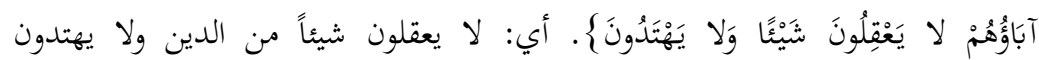

${ }^{41}$ Fakhr al-Dīn Muhammad bin 'Umar al-Tamīmī al-Shāfi'ī al-Rāzī, Al-Tafsīr al-Kabīr aw Mafätīh al-Ghayb (Beirut: Dār al-Kutub al-'Ilmiyyah, 2000), 28:226.

42 Muhammad bin Mūḥammad al-'Imādī Abū al-Sa'ūd, Irshād al- 'Aql al-Salīm ilā Mazāyā al-Qur'ān al-Karīm (Beirut: Dār Ihyē̄' al-Turath al-'Arabī, n.d.), $1: 188$

43 Nașr bin Muhammad bin Aḥamad Abū al-Layth al-Samarqandī, Tafsīr alSamarqand̄̄ al-Musammā Baḥr al-'Ulūm, taḥīq: Maḥmūẹ Miṭrajī (Beirut: Dār al-Fikr, n.d.), 1:138. 
للصواب؛؛؛ والواو في أَو لَوْ واو العطف دخلت عليها همزة الاستفهام المنقولة إلى معنى

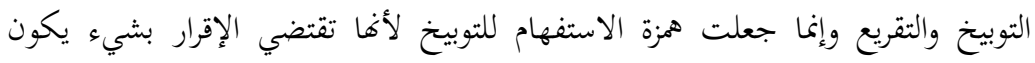
الإقرار به فضيحة كما يقتضي الاستفهام الإخبار عن المستفهم عنه.

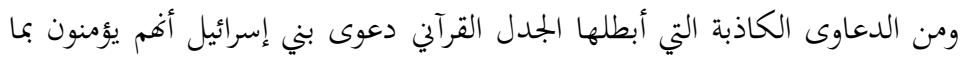

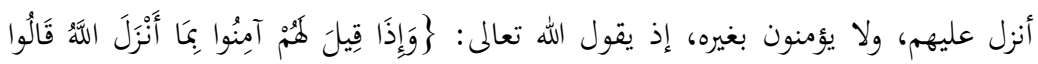

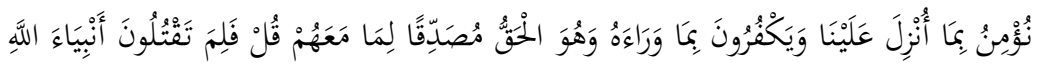

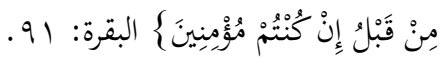

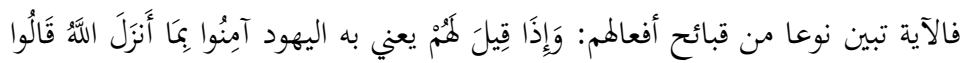

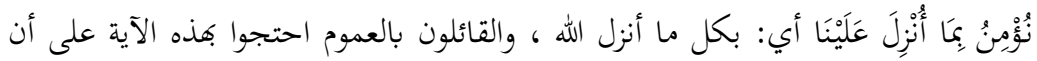

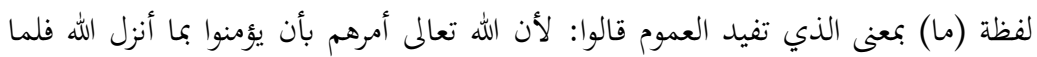

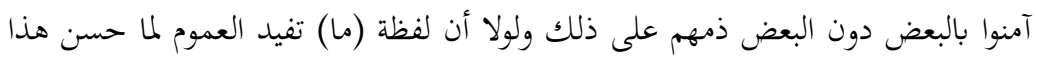

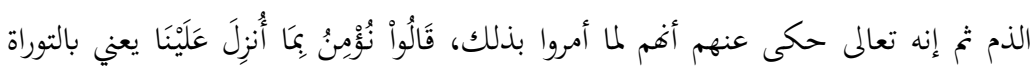

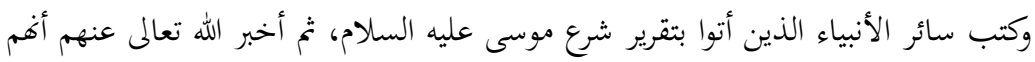

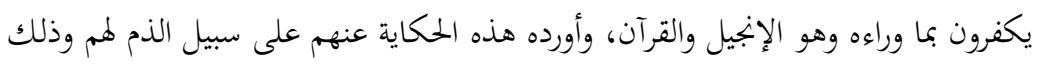

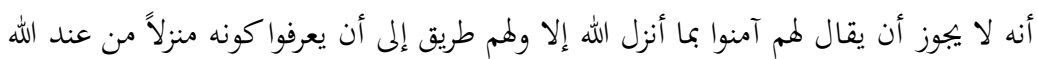

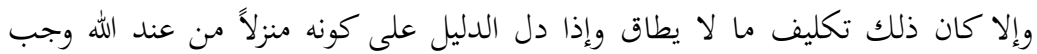

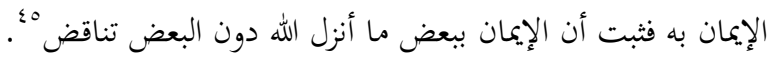

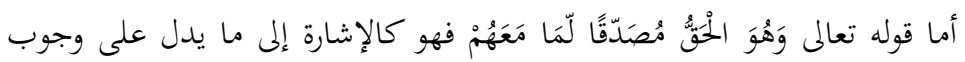

$$
\text { الإيمان بمحمد صلى الله عليه وسلم وبيانه من وجهين: }
$$

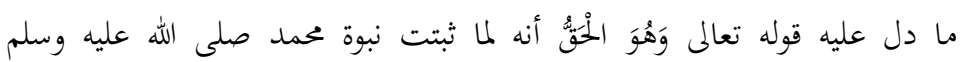

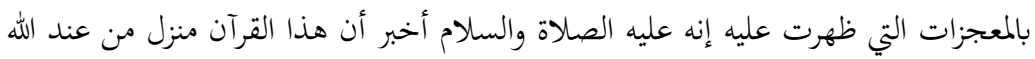

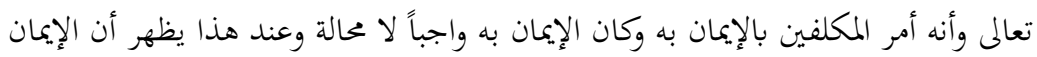

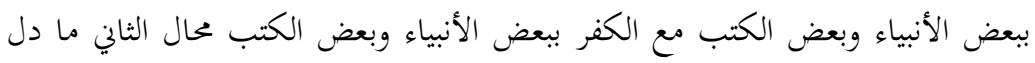

\footnotetext{
${ }^{44}$ Muhammad bin Yūṣuf Abū Hayyan al-Andalusī, Tafsìr al-Bahr al-Muhīt, taḥqīq: 'Ādil Aḥmad 'Abd al-Mawjụ̣̄ \& 'Alī Muhammad Mu'awwaḍ wa akharun (Beirut: Dār al-Kutub al-'Ilmiyyah, 2001), 1:655.

${ }^{45}$ Abū Ḥayyan al-Andalusī, Tafsìr al-Bahr al-Muhīṭ, 3:129.
} 
عليه قوله مُصَدِّقًا لمّمَا مَعُهُمْ وتقريره من وجهين الأول أن محمداً صلوات الله وسلامه عليه لم

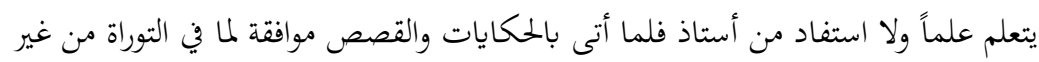
تفاوت أصلاً علمنا أنه عليه الصلاة والسلام إنما استفادها من الوحي والتنزيل.

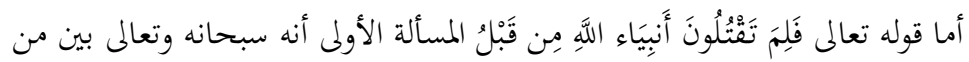

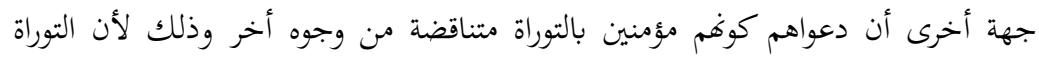

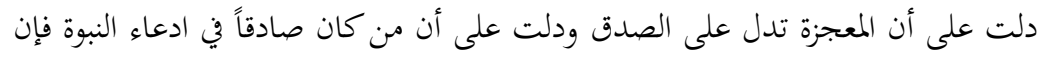
قتله كفر وإذا كان الأمر كذلك كان السعي في قتل يهيى وزكريا وعيسى عليهم السلام كفراً

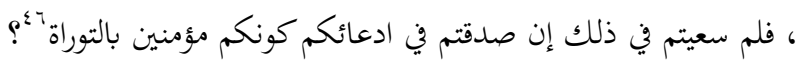

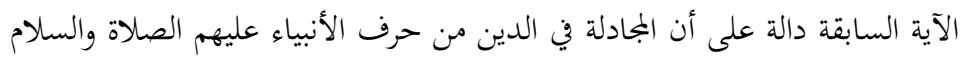

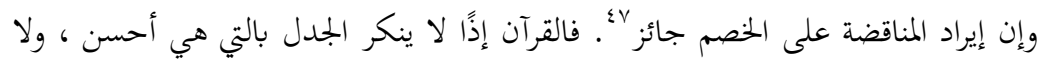

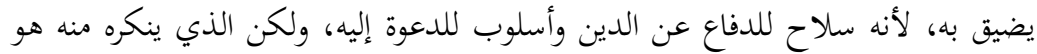

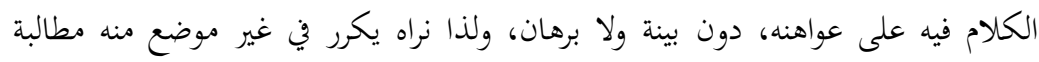

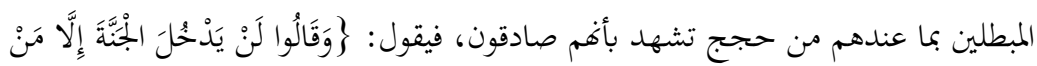

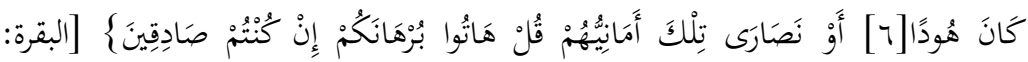

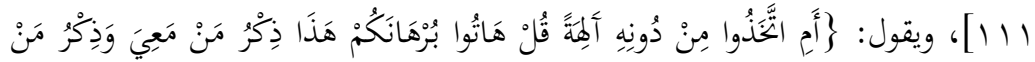

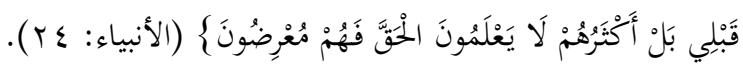

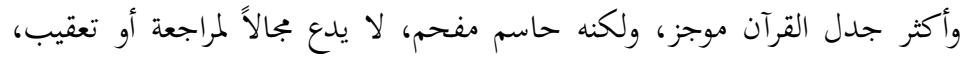

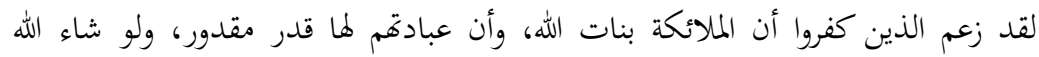

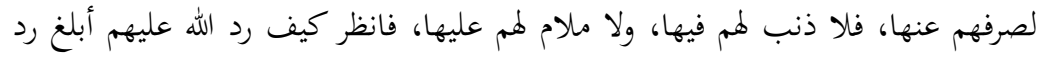

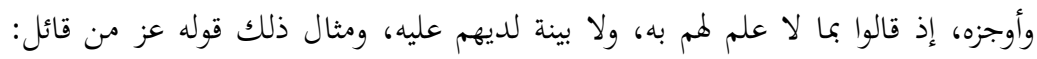

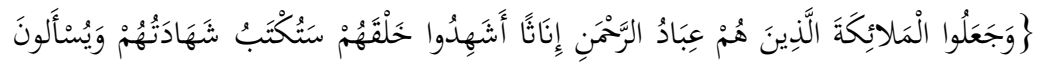

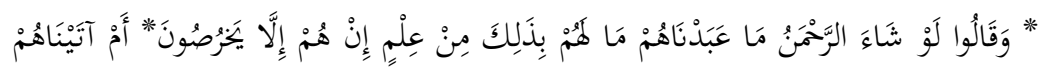

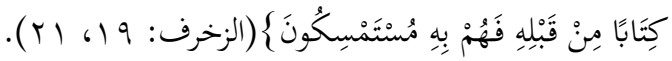

46 Abū Hayyan al-Andalusī, Tafsīr al-Baḥr al-Muḥiț, 3:129-130.

47 Abū Hayyan al-Andalusī, Tafsīr al-Baḥr al-Muḥịt, 3:130. 


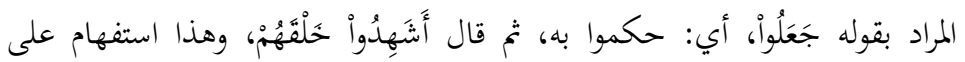

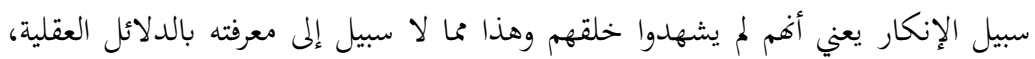

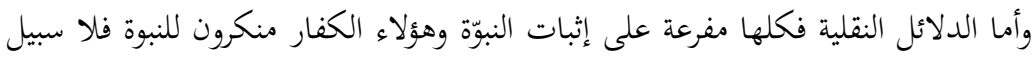

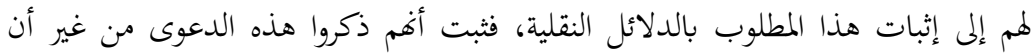

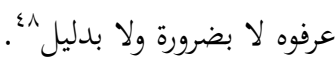
كذلك فإن القرآن الكريم يجنح أحيانًا إلى إطالة الجدل وبسط الحُُجَّة فيه، مثل ما

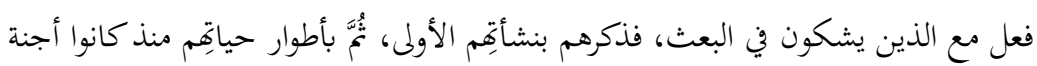

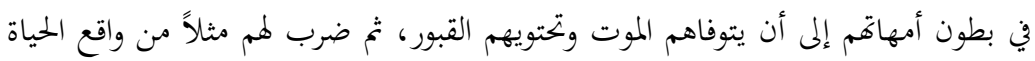

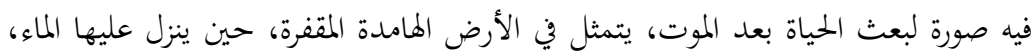

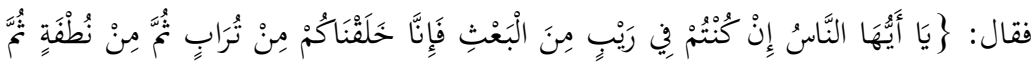

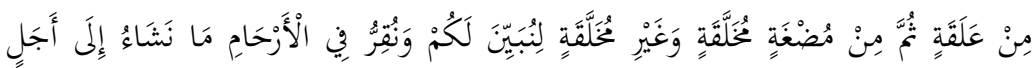

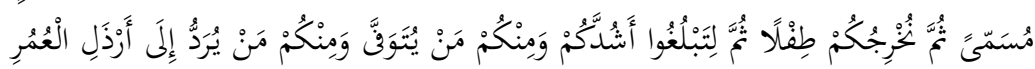

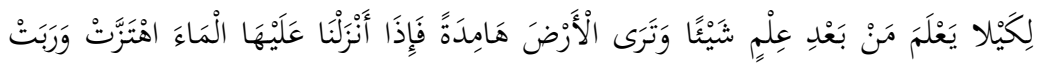

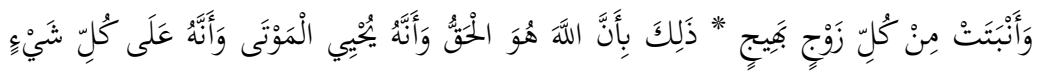

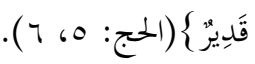

الخاتمة

في غاية هذا البحث، نذكر أهم ما توصلنا إليه من نتائج، مع الإيجاز، فنقول مستعينين

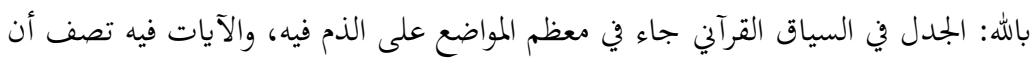

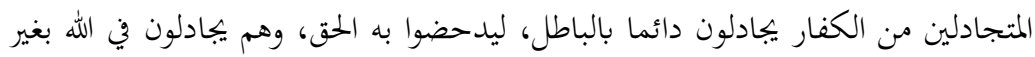

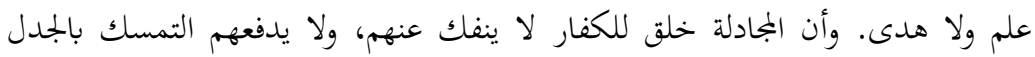

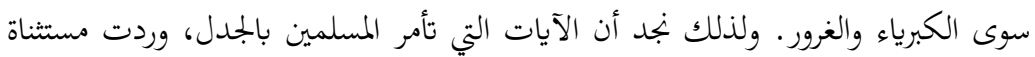

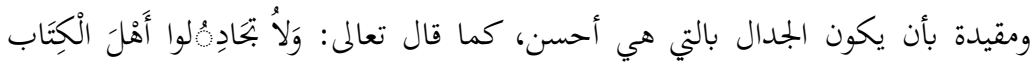

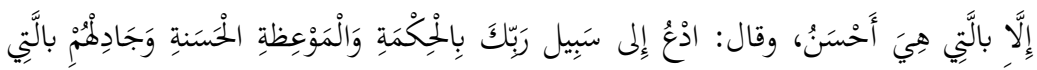

48 Abū Ḥayyan al-Andalusī, Tafsīr al-Baḥr al-Muḥịt, 27:174. 
هِيَ أَحْنَُ، ويستعمل الجدل عندما تقتضي الحاجة إليه ولا يلتجؤ إليه كل وقت وحين لأنه ليس من طبيعة المسلم وخلقه. أما الجدل عند السفسطائيين يقوم على عدة أسس تخالف الجدل القرآي أولاً: قيامه على مبدأ الشك المطلق وثانياً: أساس التلاعب اللغوي بمدلول الألفاظ، ولم يكن غاية السفسطائين البحث عن الحقيقة لذاتما وانما للوصول للمنفعة، فاستعملوا. وذهبت المدرسة السفسطائية بمفهوم الجلدل أكبر من ذلك لمناقشة.

\section{المغالطات السفسطائية العقيمة}

نستطيع ان نفهم الجدل الديالكتيكي على أنه سلسلة من عمليات متلاحقة من الصيرورة والزوال، وان الوجود في مشاقه مع نفسه يحتوي في داخله على عراك وتمزق باطني، لكنه عراك ينتهي في الخطوة التالية ولا يلبث أن يُرفع ثم يعود من جديد وهكذا باستمرار. بل ان

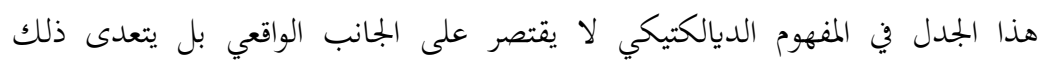
وينعكس من ديالكتيك الطبيعة إلى ديالكتيك الفكر . أما القرآن الكريم فقد مارس الجدل للوصول للحقائق من خلال البرهان والدليل الحسي والعقلي ولا يقبل الجدل القائم على الدور والتسلسل اللامتناهي نظريا وواقعياً، فالغاية في الجدل القرآي هي الوصول لليقين، لذلك سلك القرآن كل ما يتصوره العقل من الطرق والبراهين والوسائل والبيانات لإثبات الحق.

وارتبط الجدل القرآي بالدليل المستلزم سلامة الفطرة خلافاً للسفسطائية والديالكتيك التي اهملت هذا الجانب تماما: فإن هذا الارتباط ليس بالطريقة السببية الفلسفية التي يُبني على العلية أو الضرورة العقلية، فضلا عن كون المعرفة نفسها ليس طريق تحصيلها الدليل العقلي وحده، وهذا لا يعني إبطال عمل العقل، وإنما يعني ضرورة دخول الفطرة السليمة وتوجه الإنسان نحو طلب الحق مع صدق النية. يستخدم القرآن الكريم في العادة الدعوة والإقناع البرهان الخطابي، أي البرهان الذي يصلح للعامة والخاصة، ويخاطب المشاعر والوجدان، ويقيم القرآن هذا البرهان على قاعدتين عظيمتين: 1 - توجيه النظر، ب- والدعوة إلى التبصر؛ فأما توجيه النظر فإلى ملكوت ولى ولى 
السموات والأرض ، وما خلق الله فيهن من شيء، ليرى الإنسان فيه ما لم يكن يراه، أو ما

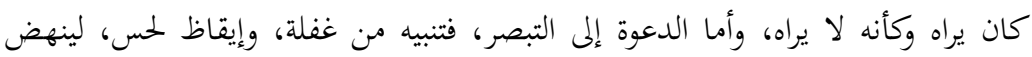

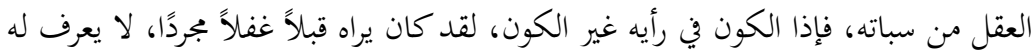

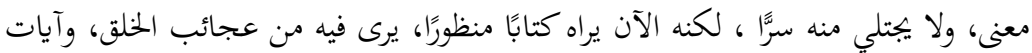
القدرة الباهرة، وإحكام التدبير.

\section{References}

'Ațā Allāḥ wa ākharun, Mukhtār. Nazariyyah al-Ma'rifah ta'șīluhā wa Ittijāhātuhā. Riyadh: Dār Madār al-Wațan, 2017.

Abū al-Sa'ūd Muḥammad bin Mūḥammad al-'Imādī. Irshād al-'Aql al-Salìm ilā Mazāyā al-Qur'ān al-Karìm. Beirut: Dār Iḥyā' al-Turath al-'Arabī, n.d.

Afalāțūn. Fì al-Sufasṭ̂̄' 'ỳ̄n wa al-Tarbiyah (Muḥ̂̄warat Brutājūrās). Tarjamah 'Izzat Qarnī. Al-Qāhirah: Dār Qubā' li al-Nashr, 2001.

Al-Alma'ī. Manāhij al-Jadal fì al-Qur'an al-Karìm. Riyadh: Mațā'bi' al-Farazdaq, n.d.

Al-Andalusī, Muhammad bin Yūṣuf Abū Hayyan. Tafsīr alBaḥr al-Muḥiṭ. Taḥqīq: 'Ādil Aḥmad 'Abd al-Mawjūḍ \& 'Alī Muhammad Mu'awwaḍ wa ākharun. Beirut: Dār alKutub al-'Ilmiyyah, 2001.

Al-Baghawī, Abū Muḥammad al-Ḥusayn ibn Mas'ūd ibn Muhammad al-Farrā'. Tafsīr al-Baghawī. Tahqīq: Khālid 'Abd Raḥman al-'Akk. Beirut: Dār al-Ma'rifah, n.d.

Al-Bayḍāwī, Naṣr al-Dīn Abū al-Sa'īe 'Abd Allāh bin 'Umar bin Muḥammad al-Shīrāzī. Tafsīr al-Bayḍ̄āì. Beirut: Dār al-Fikr, n.d.

Al-Hanbal̄i, Abū al-Wafā' 'Alī bin 'Aqeel al-Baghdādī. Kitāb al-Jadal 'alā Tarīqah al-Fuqahā'. Al-Qāhirah: Maktabah al-Thaqāfah, n.d.

Al-Ja'lī, Fatḥ al-Raḥman. Al-Īmān bi Allāh wa al-Jadal alShuyū ‘ì. Jeddah: Dār al-Su'ūdiyyah li a;-Nashr, $1984 .$. 
Al-Maydān̄i, 'Abd al-Raḥman Hasan Habannakah. Dawābit al-Ma'rifah wa Ușūl al-Istidlāl wa al-Munāzarah. Damsyik: Dār al-Qalam, 2008.

Al-Nawāwī, Yaḥyā bin Sharaf. Tahdhīb al-Asmā' wa alLughāt. Al-Qāhirah: Dar al-Tiba'ah al-Muniriyyah, n.d.

Al-Qasțanțīn̄i, Mușțafā bin 'Abd Allāh. Kashf al-Zunūn 'an Asāmī al-Kutub wa al-Funūn. Beirut: Dār al-Kutub al'Ilmiyyah, 1992.

Al-Rāzī, Fakhr al-Dīn Muhammad bin 'Umar al-Tamīmī alShāfi'‘̄. Al-Tafsīr al-Kabīr aw Mafātīh al-Ghayb. Beirut: Dār al-Kutub al-'Ilmiyyah, 2000.

Al-Rāzī, Muhammad bin Ab̄̄ Bakr bin 'Abd al-Qādir. Mukhtār al-Ṣihah. Taḥqīq: Maḥmūụ Khāṭir. Beirut: Maktabah Lubnān Nāshirūn, 1995.

Al-Samarqandī, Nașr bin Muḥammad bin Ahamad Abū alLayth. Tafsīr al-Samarqandī al-Musammā Baḥr al- 'Ulūm. Taḥqīq: Maḥmūụ Miṭrajī. Beirut: Dār al-Fikr, n.d.

Al-Shanqīī̄, Muḥammad al-Āmīn bin Muḥammad alMukhtār al-Ja'n̄̄. Aḍwa' al-Bayān fì Ị̇̂̄ḥ al-Qur'an bi AlQur'ān. Taḥqīq: Maktab al-Buhuth wa al-Dirāsāt. Beirut: Dār al-Fikr li al-Ṭibā'ah wa al-Nashr, n.d.

Al-Ṭūfì, Najm al-Dīn al-Hanbalī. 'Ilm al-Jadal fì 'Ilm alJadal. Tahqīiq: Volvhart Haynrishs. Beirut: Dār al-Nashr Franz Shtaynar Pvesbadin, 1987.

Ar Flin, Thomas. Al-Wüjūdiyyah. Tarjamah Marwah 'Abd al-Salām. Al-Qāhirah: n.p., 2014.

Ḥilmī, Amīr. Muḥāwarah Thiyātitūs li Afālațūn aw 'an al'Ilm. Al-Qāḥirah: Dār al-Gharīb li al-Nashr, 2000.

Ibn Kathīr, Ismā'īl. Tafsīr al-Qur'ān al-'Az̄ìm. Beirut: Dār al-Fikr, n.d.

Ibn Manẓūr, Muḥammad bin Mukarram al-Afrīqī al-Mișr. Lisān al-'Arab. Beirut: Dār al-Șādir, n.d.

Karam, Yūsuf. Tarīkh al-Falsafah al-Yūnāniyyah. Beirut: Dār al-Qalam, n.d. 
Koznitsof, Fasili. Ludfij Fìrubakh wa Nihayat al-Falsafah al-Kilasīkiyyah. N.p.: Dār al-Taqwīm, al-Ittihād al-Sufyit̄̄, 1978.

Mahdī, Faḍl Allāh. Madkhal ilā 'Ilm al-Manțiq, 'Ilm alMantiq al-Taqlīdī. Beirut: Dār al-Ṭalī‘ah, n.d.

Qinnawji, Șiddīq bin Hasan. Abjad al-'Ulūm al-Washī alMarqūm fì Bayān Ahwāl al- 'Ulūm. Taḥīq: 'Abd al-Jabbār Zakār. Beirut: Dār Al-Kutub al-'Ilmiyyah, 1978.

Șalibā, Jamīl. Al-Mu jam al-Falsafí. Lubnān: Dār al-Kutub al-Lubnāniyyah, 1982.

Stalīn. Al-Māddiyyah al-Diyāliktikiyyah wa al-Māddiyyah al-Tārīkhiyyah. N.p.: Dār Damsyik, n.d.

Yusuf, La' asākir. "Al-Jadal fī al-Qur'ān Khașā'ișuhu wa Dalālātuhu 'Jīiāl ba'ḍā al-Anbiyā'" Namūdhajan Dirāsah Lughwiyah Delāliyah”. Risālah Mājistīr, Wizārah alTa' ${ }^{\prime} \bar{m}$ al-Ālì wa al-Baḥth al-'Ilmī, Jāmi'ah al-Jazā'ir, 2000. 